\title{
O gênero Cnidoscolus Pohl (Crotonoideae-Euphorbiaceae) no Estado de Pernambuco, Brasil ${ }^{1}$
}

\author{
André Laurênio de Melo ${ }^{2,3}$ e Margareth Ferreira de Sales ${ }^{2}$
}

Recebido em 20/03/2007. Aceito em 12/11/2007

\begin{abstract}
RESUMO - (O gênero Cnidoscolus Pohl (Crotonoideae-Euphorbiaceae) no Estado de Pernambuco, Brasil). O gênero Cnidoscolus está representado no Estado de Pernambuco por oito espécies: C. bahianus (Ule) Pax \& K. Hoffm., C. loefgrenii (Pax \& K. Hoffm.) Pax \& K. Hoffm., C. obtusifolius Pohl, C. oligandrus (Müll. Arg.) Pax, C. quercifolius Pohl, C. urens (L.) Arthur, C. urnigerus (Pax) Pax e C. vitifolius (Mill.) Pohl reconhecidas, principalmente, pela forma da folha, tipos de tricomas urticantes nos ramos, presença e morfologia das glândulas peciolares, união e forma do perianto e número e disposição dos estames. Cnidoscolus urens ocorreu em todas as zonas fitogeográficas; $C$. loefgrenii foi registrada na zona da Mata e das Caatingas; C. quercifolius, C. obtusifolius, C. vitifolius, C. bahianus e C. urnigerus foram registradas apenas na zona das Caatingas; C. oligandrus é exclusiva da zona da Mata.
\end{abstract}

Palavras-chave: Euphorbiaceae, Crotonoideae, Cnidoscolus, taxonomia, Pernambuco

ABSTRACT - (The genus Cnidoscolus Pohl (Crotonoideae-Euphorbiaceae) in the Pernambuco State, Brazil). Eight species of Cnidoscolus were recorded in the state: C. bahianus (Ule) Pax \& K. Hoffm., C. loefgrenii (Pax \& K. Hoffm.) Pax \& K. Hoffm., C. obtusifolius Pohl, C. oligandrus (Müll. Arg.) Pax, C. quercifolius Pohl, C. urens (L.) Arthur, C. urnigerus (Pax) Pax and C. vitifolius (Mill.) Pohl. These were recognized mainly by leaf shape, type of stinging hairs on the branches, presence and morphology of petiole glands, union and shape of the perianth, and stamen arrangement. Cnidoscolus urens was found in all phytogeographical zones, C. loefgrenii in "Zona da Mata" (Moist Forest Zone) and "Zona das Caatingas" (Savannah Steppe Zone), C. quercifolius, C. obtusifolius, $C$. vitifolius, $C$. bahianus and C. urnigerus were only recorded in "Zona das Caatingas", while C. oligandrus was shown to be exclusive to "Zona da Mata".

Key words: Euphorbiaceae, Crotonoideae, Cnidoscolus, taxonomy, Pernambuco

\section{Introdução}

O gênero Cnidoscolus Pohl compreende cerca de 50-75 espécies, distribuídas exclusivamente na América tropical e concentradas, principalmente, no México e nordeste do Brasil (Webster 1994). Este gênero foi proposto por Pohl (1827) para incluir espécies que apresentavam apenas um verticilo no perianto e tricomas urticantes. Porém, Cnidoscolus não foi aceito por botânicos posteriores como Müller (1865; 1866; 1873), Pax (1910), Pax \& Hoffmann (1914) e Croizat (1943), entre outros, que preferiram tratá-lo como seção ou subgênero de Jatropha L. Após os trabalhos de Pax \& Hoffmann (1924; 1931), que revalidaram a maioria das espécies, Cnidoscolus passou a ser reconhecido por grande parte dos demais taxonomistas, alguns dos quais ressaltaram diferenças conspícuas entre este gênero e Jatropha.
McVaugh (1944) observou, além da presença de um único invólucro floral em Cnidoscolus e dois em Jatropha e dos tricomas urticantes presentes em Cnidoscolus e ausentes em Jatropha, características como glândulas peciolares, geralmente presentes em Cnidoscolus e ausentes em Jatropha, e estiletes bífidos e capitados em Jatropha e, em geral, multífidos e filiformes em Cnidoscolus, entre outras características. Trabalhos mais recentes acrescentaram distinções entre estes dois táxons quanto à morfologia do pólen, inaperturado em Jatropha e porado em Cnidoscolus (Miller \& Webster 1961; 1962; Punt 1962; Nowicke 1994), ao número de núcleos do pólen, 2-nucleados em Jatropha e 3-nucleados em Cnidoscolus (Webster \& Rupert 1973), à anatomia do pecíolo, com 6, 9 ou 11 feixes vasculares unidos na região mediana em Jatropha e com 7 feixes vasculares livres por todo o comprimento do pecíolo em Cnidoscolus (Miller \& Webster 1961; 1962), ao número

\footnotetext{
1 Parte da Dissertação de Mestrado do primeiro Autor, Universidade Federal Rural de Pernambuco

2 Universidade Federal Rural de Pernambuco, Departamento de Biologia, Área de Botânica, Av. D. Manuel de Medeiros s.n., 50171-030 Recife, PE, Brasil

3 Autor para correspondência: laureniogomes@yahoo.com.br
} 
cromossômico, $\mathrm{n}=11$ e $\mathrm{n}=22$, raro $2 \mathrm{n}=44$, em Jatropha e $\mathrm{n}=18$ ou $2 \mathrm{n}=36$ em Cnidoscolus (Miller \& Webster 1961; 1962; 1966; Hans 1973) e à morfologia dos laticíferos, inarticulados em Jatropha e articulados em Cnidoscolus (Rudall 1987).

Uma das características diagnósticas de Cnidoscolus é a presença de tricomas urticantes (Cnidoscolus, do grego: knide = urtiga, skolos = ponta; Soukup 1968) em quase todas as suas partes vegetativas e florais. Estes tricomas, quando tocados, provocam fortes dores localizadas, urticárias e até, em raros casos, desmaios (Lutz 1914; Muenscher 1958).

A primeira contribuição para o entendimento das relações interespecíficas em Cnidoscolus foi dada por Müller $(1865 ; 1866)$ que, tratando este táxon como uma seção de Jatropha, reconheceu duas subseções, diferenciadas pelo grau de união do perianto das flores pistiladas: Cnidoscolus (perianto com segmentos livres) e Calyptrosolen (perianto com segmentos concrescidos em tubo). Já Pax (1910) elevou Jatropha sect. Cnidoscolus à categoria de subgênero (Jatropha subgen. Cnidoscolus), adotando um número maior de características, como o número e disposição de estames e verticilos estaminais e a forma da folha, para subdividi-la em seis seções: Vitifoliae, Hamosae, Jussieuia, Calyptrosolen, Oligandrae e Platyandrae. A última classificação infragenérica para Cnidoscolus foi elaborada por McVaugh (1944), que considerou cinco seções (Calyptrosolen, Jussieuia, Cnidoscolus, Vitifoliae e Platyandrae) admitindo, além das características utilizados pelos autores anteriores, a presença ou ausência e morfologia das glândulas peciolares como importantes elementos para diferenciar algumas delas. A última revisão envolvendo o gênero Cnidoscolus foi elaborada por Breckon (1979), que tratou exclusivamente de espécies de Cnidoscolus sect. Calyptrosolen para o México.

Apesar de bem representado no Brasil (aproximadamente 18 espécies), especialmente na região Nordeste (com cerca de 10 espécies), que é um dos prováveis centros de diversidade de Cnidoscolus (Macbride 1951), os estudos sobre esse gênero são escassos no país. Os tratamentos taxonômicos que referem espécies brasileiras são obras clássicas e muito antigas, como o "Plantarum Brasiliae icones et descriptiones", de Pohl (1827), as monografias de Müller (1873) na "Flora Brasiliensis" e de Pax (1910), no "Das Pflanzenreich". As espécies de Cnidoscolus são constantemente referidas em levantamentos florísticos e/ou fitossociológicos no nordeste (Sales et al. 1998; Rodal et al. 1999). No entanto, este gênero tem número inexpressivo de amostras depositadas nos herbários e estas, freqüentemente, são de má qualidade. Isto, provavelmente, deve-se a presença dos tricomas urticantes.
Embora pouco aproveitadas economicamente, várias são as formas em que as espécies do gênero Cnidoscolus podem ser empregadas, tais como: forrageira (Bezerra 1972; Passos 1993; Lima 1998), oleífera (Bondar 1942; Santa Rosa 1943; Mors \& Rizzini 1966), laticífera (Williams 1962), na medicina caseira (Braga 1976) e ornamentais (Ingram 1957; Pott \& Pott 1994).

O presente trabalho tem como objetivos identificar e descrever as espécies ocorrentes no estado de Pernambuco, ressaltando características morfológicas relevantes para o seu reconhecimento, incluindo comentários sobre afinidades, sinonímias e habitats preferenciais, além de ilustrá-las e atualizar informações sobre distribuição geográfica.

\section{Material e métodos}

Área de estudo - O Estado de Pernambuco localiza-se na região Nordeste do Brasil, entre as coordenadas $7^{\circ} 15^{\prime} 45^{\prime \prime}$ 'S e $9^{\circ} 28^{\prime} 18^{\prime \prime} \mathrm{S}$ e $34^{\circ} 48^{\prime} 35^{\prime \prime} \mathrm{W}$ e $41^{\circ} 19^{\prime} 54^{\prime \prime} \mathrm{W}$ e ocupa uma área de $98.079 \mathrm{~km}^{2}$ (Andrade-Lima 1961). De acordo com Andrade-Lima (1957), este Estado está dividido em quatro zonas fitogeográficas: Litoral, Mata, Caatingas e Savanas. A zona da Mata foi dividida ainda nas subzonas da Mata Seca e da Mata Úmida; a zona das Caatingas nas subzonas Agreste, Sertão e Matas Serranas; e a zona das Savanas em Tabuleiros e Agrestes do Araripe. Na subzona do Sertão o autor reconheceu ainda as regiões do Sertão Central, do Jatinã, do São Francisco, do Araripe e dos Chapadões Cretáceos.

Estudo taxonômico - Foi baseado na análise morfológica comparativa de plantas observadas no campo, e de materiais herborizados. Foram percorridos cerca de 65 municípios de Pernambuco, englobando diferentes zonas fitogeográficas para coleta de material botânico e estudo de populações. Durante as coletas seguiu-se a metodologia proposta por Mori et al. (1989). O material coletado foi depositado no Herbário PEUFR, da Universidade Federal Rural de Pernambuco. Foram analisadas exsicatas provenientes de diversos herbários do país (siglas de acordo com o Index Herbariorum, Holmgren et al. 1990): ALCB, ASE, CEN, CPATSA, CVRD, EAC, ESA, ESAL, HST, IBGE, SP, IPA, MBML, MG, PACA, PEUFR, R, RB, SPSF, TEPB, UB, UFMT, UFP, VIC.

A identificação dos táxons foi procedida com base nas obras clássicas, tipos e fotografia de tipos e, principalmente, na análise das populações. Alguns trabalhos serviram de referência para definir terminologias para forma e distribuição dos tricomas, forma das folhas e partes foliares (Lawrence 1973; Hickey 1973; Radford et al. 1974). A abreviatura das 
obras onde as espécies foram publicadas seguiu Stafleu \& Cowan (1976). Dados de distribuição geográfica e períodos de floração e frutificação foram obtidos através de consultas às etiquetas do material examinado, e de observações no campo.

Aspectos morfológicos relevantes - Tricomas - Em Cnidoscolus estão presentes tricomas urticantes e não urticantes. Os tricomas urticantes são formados por uma única célula tubular, alongada, com paredes distais silicosas, situada sobre uma base multicelular e com uma abertura oblíqua no ápice (Thurston \& Lestern 1969). Dois tipos de tricomas urticantes são observados nas espécies de Pernambuco: a) aciculiforme - tricoma com base cilíndrica ou cônica, ligeiramente rígida ou flácida, sustentando uma célula tubular longa. É encontrado em quase todas as partes vegetativas e florais da maioria das espécies; e b) aculeiforme - tricoma com base alargada, cônica, rígida, sustentando um célula tubular muito curta, observado apenas nos ramos de $C$. bahianus e C. obtusifolius. Tricomas urticantes aciculiformes com base inflada e notoriamente turgescente também são encontrados em algumas partes vegetativas ou florais como, freqüentemente, no pecíolo de $C$. bahianus e nos frutos de C. loefgrenii (Fig. 24), C. urens, C. quercifolius (Fig. 82) e C. urnigerus. Estes tricomas quando presentes no material fresco apresentam-se túrgidos. Os tricomas não urticantes, simples, unicelulares, formam indumento pubescente, velutino, tomentoso, pubérulo, viloso etc. e revestem a maioria das espécies, em partes vegetativas e florais. Tricomas lactescentes, unicelulares, estão presentes em Cnidoscolus loefgrenii, C. urnigerus e C. urens. Em material verde, estes tricomas ao serem tocados com estilete expelem, imediatamente pelo ápice, gotículas de látex; estas mesmas gotículas também são observadas em material desidratado. Tricomas latescentes não têm sido mencionados na literatura para Cnidoscolus. No entanto, Castells et al. (1984) observaram laticíferos chegando à célula basal de tricomas foliares em Jatropha gossypifolia L.

Lâmina foliar - Na maioria das espécies de Pernambuco é geralmente 3-5(-7) palmatilobada, mas também pode ser pinatilobada ou inteira como em $C$. quercifolius e inteira em C. obtusifolius. Todas as espécies estudadas são caracteristicamente palmatinérveas e o número de nervuras primárias pode ser $3,5,7$ ou 9 , raramente 13 , sendo geralmente superior ao número de lobos.

Glândulas peciolares - Reúnem características relevantes para a circunscrição de seções e subseções em Cnidoscolus (McVaugh 1944). Estas glândulas estão localizadas na porção adaxial do ápice do pecíolo, na sua junção com a lâmina foliar ou, ainda, sobre uma plataforma glandular, que parece ser um espessamento da base da lâmina foliar prolongada, em direção ao pecíolo. Nas espécies de Pernambuco, tais glândulas estão presentes na maioria das espécies e ausentes em C. obtusifolius e C. quercifolius. Quando presentes, podem ocorrer na junção do pecíolo com a lâmina ou logo abaixo desta região. São em número de duas (raramente uma), laminares, com papilas na face interna em $C$. oligandrus, ou numerosas e papiliformes, formando um ou dois conjuntos, na maioria das espécies.

Perianto - Monoclamídeo, varia tanto na forma como na união dos segmentos. Nas espécies estudadas, o perianto das flores estaminadas é formado por segmentos unidos em um tubo de comprimento variável, sendo hipocrateriforme (maioria das espécies), campanulado a infundibuliforme ou urceolado. As flores pistiladas, na maior parte do gênero, possuem perianto com segmentos livres, mas algumas espécies podem apresentar diferentes graus de união, e até um perianto quase totalmente unido. Nas espécies de Pernambuco foram observados periantos com segmentos inteiramente livres a curta a longamente unidos. A forma como o perianto das flores pistiladas desprende-se após a antese, também pode variar entre as espécies. Nas espécies com segmentos inteiramente livres, cada segmento desprende-se isoladamente. Em alguns indivíduos de Cnidoscolus urens, que apresentam os segmentos ligeiramente unidos, eles desprendem-se como uma unidade e se rompem apenas em um ponto entre dois segmentos quaisquer. Já em $C$. loefgrenii, que possui tubos mais longos, os segmentos desprendem-se em conjunto, como uma unidade. Em algumas espécies, quando o perianto das flores pistiladas cai, deixa uma porção da estrutura laminar. Esta estrutura, pela carência de estudos anatômicos que definam sua natureza, tanto pode ser denominada de "base persistente do perianto", quanto interpretada como sendo uma "expansão do receptáculo". Tal porção pode ser inteira ou ligeiramente denteada ou fortemente denteada.

Androceu - O número de estames e de verticilos estaminais são importantes características para a delimitação de espécies em Cnidoscolus. Nas espécies de Pernambuco, os estames variam entre 4-25, sendo dispostos em 2 a 6 verticilos heterodínamos, cada um em geral com 5 estames, sendo os externos geralmente menores que os internos. Cnidoscolus bahianus (Fig. 12) e C. vitifolius (Fig. 160) apresentam (11-)15-20(-22) estames, distribuídos por 3 ou 4 verticilos, todos quase completamente unidos em uma única coluna. Esta mesma disposição é também encontrada em C. obtusifolius (Fig. 51), sendo que o número de estames é freqüentemente maior (15-25) e, algumas vezes, foram observados até 5 verticilos estaminais. Em C. urens (Fig. 111 e 119), C. loefgrenii (Fig. 32), C. urnigerus 
(Fig. 139) e C. quercifolius (Fig. 91) são encontrados apenas 2 verticilos estaminais e geralmente 10 estames. Em C. oligandrus são também encontrados 2 verticilos, embora com apenas 4-6 estames (Fig. 72). Estaminódios são comuns em todas as espécies estudadas, sempre filiformes e, inseridos entre os estames do verticilo interno. Em Cnidoscolus quercifolius, os estaminódios podem apresentar-se alargados no ápice e até mesmo possuir pequenas anteras estéreis (sem grãos de pólen).

Tratamento taxonômico

Cnidoscolus Pohl, Pl. bras. icon. descr. 1: 56. 1827.

Árvores, arbustos, subarbustos ou mais raramente ervas, monóicos, latescentes e com tricomas urticantes. Estípulas usualmente presentes. Pecíolo freqüentemente longo, com ou sem glândulas. Folhas alternas, palmatilobadas, pinatilobadas ou inteiras, raramente palmatífidas e palmatinérvias. Inflorescência terminal (às vezes, pseudo-axilar), dicasial. Flores monoclamídeas, unissexuais, as estaminadas nas ramificações distais e eixos terminais da inflorescência, tubulosas; as pistiladas nas terminações proximais, com segmentos do perianto livres ou parcialmente unidos. Estames 4-30, livres ou unidos em 2-6 verticilos heterodínamos, com diferentes graus de união, muitas vezes formando uma coluna conspícua; estaminódios 0-5, filiformes; grãos de pólen esferoidais ou oblato-esferoidais, pantoporados ou 3-zonocolpados, com exina de padrão croton. Ovário 3(-5) carpelar, óvulos 1 por lóculo, estiletes bífidos ou multífidos, livres ou parcialmente unidos. Fruto cápsula loculicida e septicida, raramente drupáceo. Sementes carunculadas, raramente não carunculadas, com endosperma conspícuo; embrião estreito, cotilédone largo e maior que a radícula.

Chave para as espécies de Cnidoscolus no Estado de Pernambuco

1. Lâmina foliar inteira ou pinatilobada, com a margem inteira ou crenada; pecíolo sem glândulas

2. Ramos com tricomas urticantes aculeiformes; folhas elípticas, obovais a orbiculares; estames 15-25 em 3-5 verticilos 3. C. obtusifolius

2. Ramos com tricomas urticantes aciculiformes; folhas geralmente pinatilobadas ou, às vezes, inteiras ovais a oblanceoladas ou irregularmente triangulares; estames (8-)10(-14) em 2 verticilos

5. C. quercifolius

1. Lâmina foliar palmatilobada, se inteira, então margem denteada; pecíolo com glândulas no ápice ou na junção com a lâmina.

3. Árvores de grande porte, $8-20 \mathrm{~m}$ de altura; glândulas peciolares 1 a 2 na junção com a lâmina, laminares, internamente multipapiladas; estames 4-6; fruto drupáceo, indeiscente, extremamente rígido; sementes não carunculadas

4.C. oligandrus

3. Ervas, subarbustos, arbustos ou árvores de pequeno porte, até $7 \mathrm{~m}$ de altura; glândulas peciolares numerosas, próximas ao ápice ou na junção com a lâmina, papiliformes, agrupadas em 1 ou 2 conjuntos; estames 8-22; fruto capsular loculicida-septicida com deiscência explosiva; sementes carunculadas.

4. Estames (8-)10(-12) em 2 verticilos.

5. Perianto das flores estaminadas e pistiladas urceolado. Filetes do verticilo interno e externo inteiramente livres 7. C. urnigerus

5. Perianto das flores estaminadas e pistiladas hipocrateriforme ou flores pistiladas com segmentos livres a ligeiramente unidos. Filetes do verticilo interno sempre unidos na base, e filetes do verticilo externo livres a unidos.

6. Perianto das flores pistiladas com segmentos livres ou unidos por até 2,5 $\mathrm{mm}$ compr., campanulado; base persistente do perianto fortemente denteada

6. C. urens

6. Perianto das flores pistiladas com segmentos unidos por $4-8 \mathrm{~mm}$ compr., tubularhipocrateriforme; base persistente do perianto inteira ou discretamente denteada .. 2. C. loefgrenii

4. Estames 11-22 em 3 ou 4 verticilos

7. Ramos com tricomas urticantes aculeiformes; estames unidos em coluna glabra ou pubescente; frutos imaturos com listras brancas na linha de deiscência 1. C. bahianus

7. Ramos com tricomas urticantes aciculiformes; estames unidos em coluna densamente vilosa na base; frutos imaturos completamente verdes 8. C. vitifolius 
1. Cnidoscolus bahianus (Ule) Pax \& K. Hoffm., in Engl. \& Prantl, Nat. Pflazenfam. ed. 2. 19c: 164. 1931.

Jatropha bahiana Ule, in Engl., Bot. Jahrb. Syst. 42: 220. 1909. Tipo: Brasil, Bahia, Calderão, outubro 1906, Ule 7056 (Holótipo, B, n.v.; isótipo L!; fotografia do holótipo, IPA!).

Fig. 1-20

Arbusto, arvoreta ou árvore 2-7 m alt. Tricomas urticantes aculeiformes 1-4,5 mm compr., nos ramos; tricomas urticantes aciculiformes, $1-5,5 \mathrm{~mm}$, no pecíolo, lâmina foliar, inflorescência, perianto e fruto. Ramos cilíndricos, pubérulos a velutinos no ápice ou ramos jovens. Estípulas 1-3×1-3 mm, caducas, triangulares, com margem e face interna glanduloso-papilada. Pecíolo 2,3-7,3 cm compr., glabro a tomentoso, tricomas urticantes, recurvados e com base turgescente; glândulas numerosas, dispostas em 1 ou 2 conjuntos, papiliformes, na junção do pecíolo com a lâmina. Lâmina foliar 3,3-14×3,3-16,5 cm, cartácea, 3-5-palmatilobadas ou raramentente inteira, oval, base sagitada, ápice acuminado, mucronado, margem denteada, às vezes ciliadas por tricomas urticantes, ambas as face em tricomas urticantes, a superior pubescente a tomentosa, inferior velutino-vilosa, folhas jovens às vezes densamente velutinas em ambas as faces, nervação craspedódromo-broquidódroma, nervuras primárias 7 ou 9. Inflorescência 8-35 dicásios, dispostos em 4-6 níveis de ramificação, 1,1-5×2,7-7 cm, pubérula a tomentosa, geralmente sem tricomas urticantes; pedúnculo 0,6-6,5 cm compr.; brácteas 1,5-3,5(-13) mm compr., triangulares, raramente foliáceas, elípticas, ou trilobadas, margens glanduloso-papiladas na porção basal, pubescentes ou tomentosas. Botões florais estaminados obovóides, pistilados oblongo-ovóides. Flores estaminadas sésseis, posicionadas a partir do $3^{\circ}$ nível de ramificação; perianto $13,5-16,5 \mathrm{~mm}$ compr., tubularhipocrateriforme, branco ou creme, pubérulo, sem tricomas urticantes; tubo 7,5-10×2-5 mm; lobos 4,5-8×3,5-5 mm, elípticos a obovais, ápice arredondado; estames férteis 13-22, em 3-4 verticilos, quase completamente unidos em coluna 7,5-9,5 mm compr., glabra a pubescente; filetes $1,5-10,5 \mathrm{~mm}$; estaminódios $2-5$, filiformes, 8,8-13mm compr.; disco glandular $0,3-0,8 \times 0,7-1 \mathrm{~mm}$, anelar, com estrias longitudinais, freqüentemente lobado nos botões. Flores pistiladas 2-7, posicionadas até o $3^{\circ}$ nível de ramificação, sésseis ou pedicelo com até $2 \mathrm{~mm}$ compr.; receptáculo/base persistente do perianto, incospícua; perianto $11-17 \mathrm{~mm}$ compr., branco ou creme, com segmentos livres, pubérulo, sem tricomas urticantes; lobos livres, oblanceolados a obovado-oblanceolados, ápice arredondado; ovário oblongo ou ovóide, subcilíndro em seção transversal, freqüentemente com listras esbranquiçadas nas linhas de deiscência, pubérulo a velutino, geralmente sem tricomas urticantes; estiletes 3-4 mm compr, livres ou ligeiramente unidos na base, multífidos, 23-30 ramos estigmatíferos, glabros; disco glandular 0,7-1×1,5-2,5 mm, anelar. Cápsula loculicida e septicida 12,2-17,8×8,8-12,1 mm, ovóide ou elipsóide, cilíndrica ou ligeiramente triangular em seção transversal, ápice acuminado, superfície rugosa, linhas de deiscência esbranquiçadas quando imaturos, pubescente, às vezes sem tricomas urticantes; columela ca. $11 \mathrm{~mm}$ compr. Semente 12-13,3×6,8-7,6 mm, oblonga, côncava dorsalmente, convexa ou plana ventralmente, superfície marrom com máculas proeminentes mais escuras e/ou esbranquiçadas, base retusa, ápice agudo; carúncula $1,5 \times 3 \mathrm{~mm}$.

Material examinado selecionado: BRASIL. Pernambuco: Bodocó, 1/IX/1998, veg., Laurênio et al. 1261 (PEUFR); Floresta, 23/IV/1989, fl., Araújo 11 (IPA); Ibimirim, 16/II/1996, fl. fr., Laurênio et al. 311 (PEUFR); Mirandiba, 17/VII/1998, fl. fr., Laurênio et al. 1119 (PEUFR); Ouricuri, 11/IX/1968, fl., Carvalho 72 (HST); Parnamirim, 22/VIII/1984, fl. fr., Araújo 101 (PEUFR, IPA); Petrolina, 13/I/1983, fl. fr., Fotius 3303 (CPATSA); Santa Maria da Boa Vista, 8/XII/1971, fl., Andrade-Lima et al. 1213 (ASE, IPA, PEUFR); São José do Belmonte, 11/X/1997, fl., Miranda et al. 2895 (HST); Serra Talhada, 6/II/1998, fl. fr., Laurênio et al. 748 (PEUFR); Serrita, 1949, fl., Andrade-Lima 49-155 (IPA); Restrita à região nordeste do Brasil (BA, PE e PI). Em Pernambuco é encontrada na zona das Caatingas, subzona do Sertão (Fig. 168b), especialmente em vegetação de caatinga e sobre solo tipicamente argiloso ou argilo-arenoso. Floresce e frutifica de julho a abril. Conhecida popularmente como "favela-branca" (BA), "favela-braba" (BA), "favela-brava" (BA, PE e PI) e "favela-de-galinha" (PE).

É facilmente reconhecida pela presença de tricomas urticantes aculeiformes nos ramos e pelas folhas palmatilobadas, raramente inteiras, ovais, com margem denteada. Cnidoscolus bahianus é próxima de C. vitifolius, com a qual compartilha o hábito arbustivo ou arbóreo de pequeno porte, as folhas geralmente palmatilobadas e com margem denteada, as glândulas peciolares agrupadas em 1 ou 2 conjuntos e estames em número de 11-22, dispostos em 3 ou 4 verticilos. No entanto, diferenciam-se porque em C. bahianus os ramos apresentam tricomas urticantes aculeiformes (Fig. 2) e a base da coluna estaminal apresenta-se glabra (Fig. 12) ou pubescente, enquanto em $C$. vitifolius os tricomas urticantes nos ramos são aciculiformes (Fig. 149) e a coluna estaminal é vilosa na base (Fig. 160). Além disso, em C. bahianus as glândulas peciolares localizam-se 


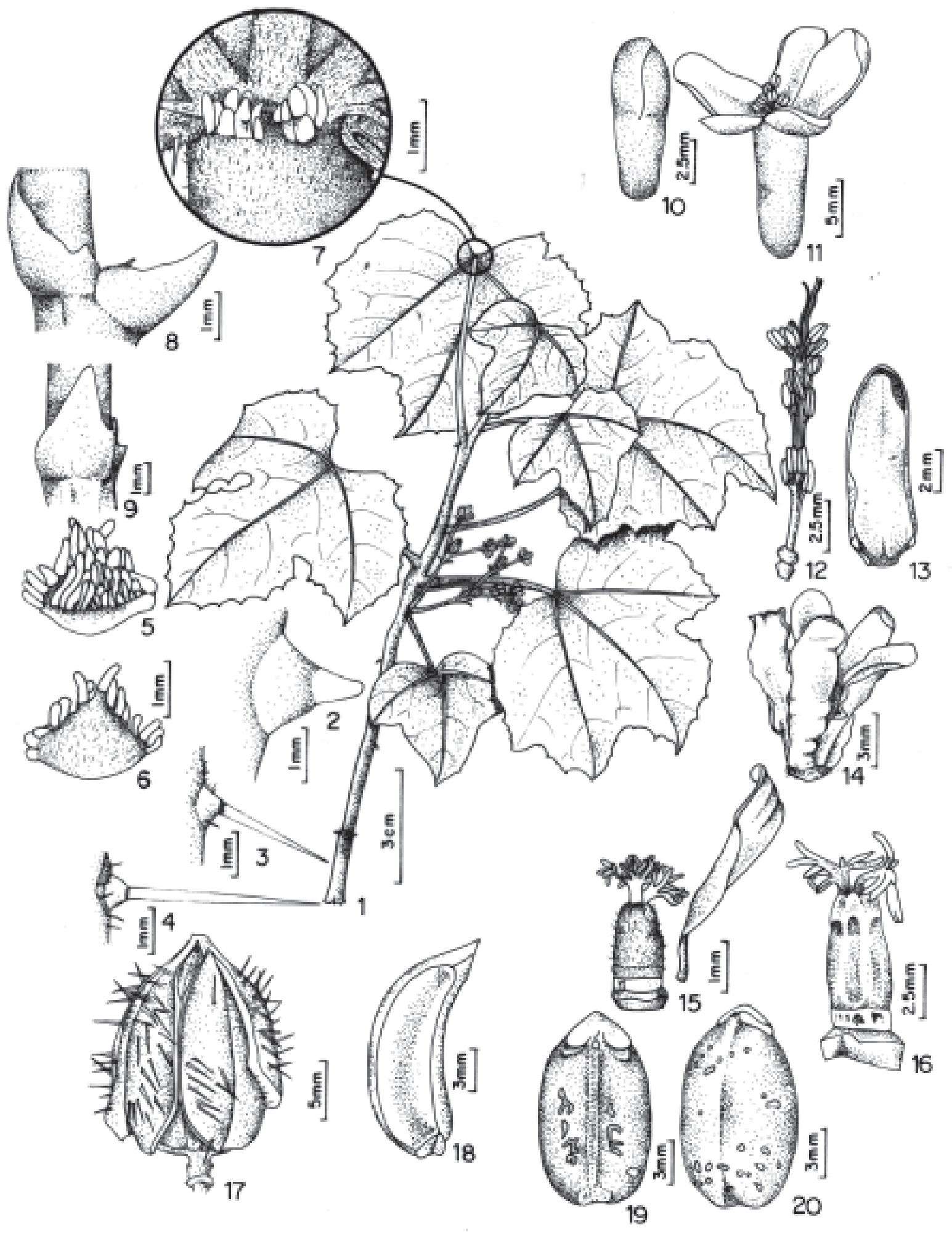

Figuras 1-20. Cnidoscolus bahianus (Ule) Pax \& K. Hoffm. 1. Ramo florido (Agra s.n. \& Belo, PEUFR 9757). 2. Tricoma urticante aculeiforme no ramo. 3. Tricoma urticante aciculiforme no pecíolo (Laurênio 748, Andrade \& Sacramento). 4. Tricoma urticante aciculiforme no fruto (Laurênio 749, Andrade \& Sacramento). 5. Face interna da estípula. 6. Face externa da estípula. 7. Glândulas peciolares (Laurênio 1124 et al.). 8. Brácteas em vista lateral. 9. Brácteas em vista frontal (Laurênio 311, Tschá \& Gomes). 10. Botão masculino. 11. Flor masculina (Miranda 2895 et al.). 12. Androceu (Laurênio 748, Andrade \& Sacramento). 13. Botão feminino (Laurênio 1124 et al.). 14. Flor feminina (Laurênio 749, Andrade \& Sacramento). 15. Desprendimento do perianto da flor feminina (Laurênio 1124 et al.). 16. Gineceu. 17. Fruto (Laurênio 749, Andrade \& Sacramento). 18. Valva do fruto. 19. Semente, face ventral. 20. Semente, face dorsal (Laurênio 1124 et al.). 
exatamente na junção do pecíolo com a lâmina foliar, enquanto em $C$. vitifolius aquelas parecem estar sempre situadas no ápice do pecíolo, logo abaixo da junção do pecíolo com a lâmina. O perianto das flores estaminadas de $C$. bahianus é tubular-hipocrateriforme (Fig. 11), com os lobos proporcionalmente mais longos que em C. vitifolius, enquanto que nesta espécie o perianto é tubular-campanulado (Fig. 159) ou tubularinfundibuliforme e os lobos são mais curtos. O ovário de $C$. bahianus possui forma oblonga ou ovóide e durante o seu desenvolvimento (observável em exsicatas com diferentes estádios de frutificação) sofre uma constricção na porção superior, tornando-se gradativamente acuminado. O mesmo não acontece com os frutos de C. vitifolius, que desde a fase de ovário são piriformes e permanecem acuminados, apenas aumentando de volume ao se desenvolverem. Os frutos imaturos de C. bahianus têm freqüentemente coloração branca ou esbranquiçada nas linhas de deiscência, tanto dos lóculos quanto dos septos, enquanto os frutos de C. vitifolius são completamente verdes.

2. Cnidoscolus loefgrenii (Pax \& K. Hoffm.) Pax \& K. Hoffm., in Engl. \& Prantl, Nat. Pflanzenfam. ed. 2. 19c: 166. 1931.

Jatropha loefgrenii Pax \& K. Hoffm., in Engl., Pflanzenr. IV. 147, I: 107. 1910. Tipo: Brasil, São Paulo, Araraquara, Löfgren 4300 (Holótipo, SP!).

Fig. 21-40

Erva ou subarbusto $0,6-2,2 \mathrm{~m}$ alt. Tricomas urticantes 0,5-14 mm compr. revestindo ramos, pecíolo, lâmina foliar, inflorescência, perianto e fruto. Ramos subcilíndricos a angulosos, pubescentes a velutinos. Estípulas 1-5×1-2,5 mm, caducas, triangulares, face interna e margem glanduloso-papiladas e/ou inteiramente glanduloso-fimbriadas, pubescentes. Pecíolo (3,3-)4,5-25 cm compr., cilíndrico, pubérulo a pubescente, às vezes viloso; glândulas na junção do pecíolo com a lâmina numerosas, papiliformes. Lâmina foliar 2,2-16(-21)×4,3-26 cm, membranácea a cartácea, (3-)5-(7-)-palmatilobada, base cordado-sagitada ou sagitada, ápice apiculado, acuminado ou arredondadomucronado, margem denteada, raramente inteira ou até ligeiramente crenada, ciliada, com ou sem apículos glandulares em cada ponto de terminação das nervuras primárias e secundárias, face superior pubescente a glabrescente, inferior pubérula a glabrescente, tricomas urticantes apenas sobre as nervuras, nervação craspedódroma a ligeiramente broquidódroma no ápice, nervuras primárias 5, 7 ou 9(-13). Inflorescência com 23-62 dicásios, dispostos em 4-6 níveis de ramificação, $2,2-6,5(-9,2) \times(1,2-) 3-10,5(-15,5) \mathrm{cm}$, pubérula a pubescente; pedúnculo (1,3-)3-23 cm; brácteas e bractéolas 1-4 mm compr., estreitamente triangulares a lanceoladas, papilas glandulosas lateralmente próximo a base, glabras a pubescentes. Botões florais estaminados geralmente oblongos, ligeiramente constricto na junção do tubo com os lobos, pistilados ovóides a piriformes. Flores estaminadas sésseis, posicionadas a partir do $4^{\circ}$ nível de ramificação; perianto 8,5-18 $\mathrm{mm}$ compr., tubular-hipocrateriforme, ligeiramente constrito logo abaixo dos lobos, branco, às vezes externamente esverdeado, pubescente; tubo (4-)6-13×2,5-5,5 mm; lobos 2,5-5,5×2,5-5 mm, ovais a suborbiculares ou oblongos, ápice arredondado; estames férteis 10 , dispostos em 2 verticilos, estames externos livres ou unidos pelos filetes até $0,5 \mathrm{~mm}$ compr., estames internos unidos até aproximadamente a metade do comprimento dos filetes; filetes 1,8-7,5 mm compr.; anteras 0,6-1,5×0,6-1 mm, dorsifixas, elípticas, suborbiculares ou oblongas; estaminódios $0-2$, filiformes, até $5 \mathrm{~mm}$ compr., entre os estames do verticilo interno; disco glandular 2,4-4×0,5-2,5 mm, anelar, ligeiramente lobado internamente. Flores pistiladas 4-18, posicionadas até o $4^{\circ}$ nível de ramificação; pedicelo 1-5 mm compr.; receptáculo/base persistente do perianto inteira ou ligeiramente denteada; perianto 7,5-12 $\mathrm{mm}$ compr., tubular-hipocrateriforme a tubular-urceolado, branco ou branco-esverdeado, pubérulo a pubescente, urticante; tubo 4-8×3-9 mm; lobos 2,5-5×1,5-3 mm, ovais a obovais, ápice arredondado; ovário ovóide ou suboblongo, cilíndrico ou 3-6 anguloso em seção transversal, pubescente a velutino; estiletes $2,5-5 \mathrm{~mm}$ compr., livres ou unidos na base por até $1 \mathrm{~mm}$ compr., tetráfidos ou multífidos com 12-16 ramos estigmatíferos, pubescentes; disco glandular 1-1,5×2-3 mm, anelar, pubescente a velutino. Fruto $7-10 \times 5,8-8,5 \mathrm{~mm}$, capsular loculicida e septicida, deiscência fortemente explosiva, subglobóide a oblongo, cilíndrico a triangular em seção tranversal, ápice emarginado a arredondado, às vezes apiculado, superfície rugosa, híspido-pubescente, tricomas urticantes laxos ou densamente dispostos; columela 5-7,5 mm compr. Semente 6-9 $9 \times 3-5 \mathrm{~mm}$, elipsóide a oblonga, côncava dorsalmente, convexa ou plana ventralmente com uma linha central depressa, superfície com máculas proeminentes marromacinzentadas ou raro inteiramente marrom-escura, quando imatura amarelada ou esbranquiçada, ápice agudo ou raramente obtuso, base truncada; carúncula $1-2 \times 2-3 \mathrm{~mm}$.

Material examinado selecionado: BRASIL. Pernambuco: Bezerros, 4/X/1983, fl., Gallindo et al. s.n. (IPA 42335); Brejo da Madre de Deus, 11/VI/1998, fl. fr., Laurênio et al. 1071 (PEUFR); Buíque, 12/IV/1997, fr., Laurênio et al. 461 (PEUFR); Cabrobó, 22/V/1984, fl. fr., Salgado et al. 382 (IPA); Camaragibe, 14/VI/1998, 


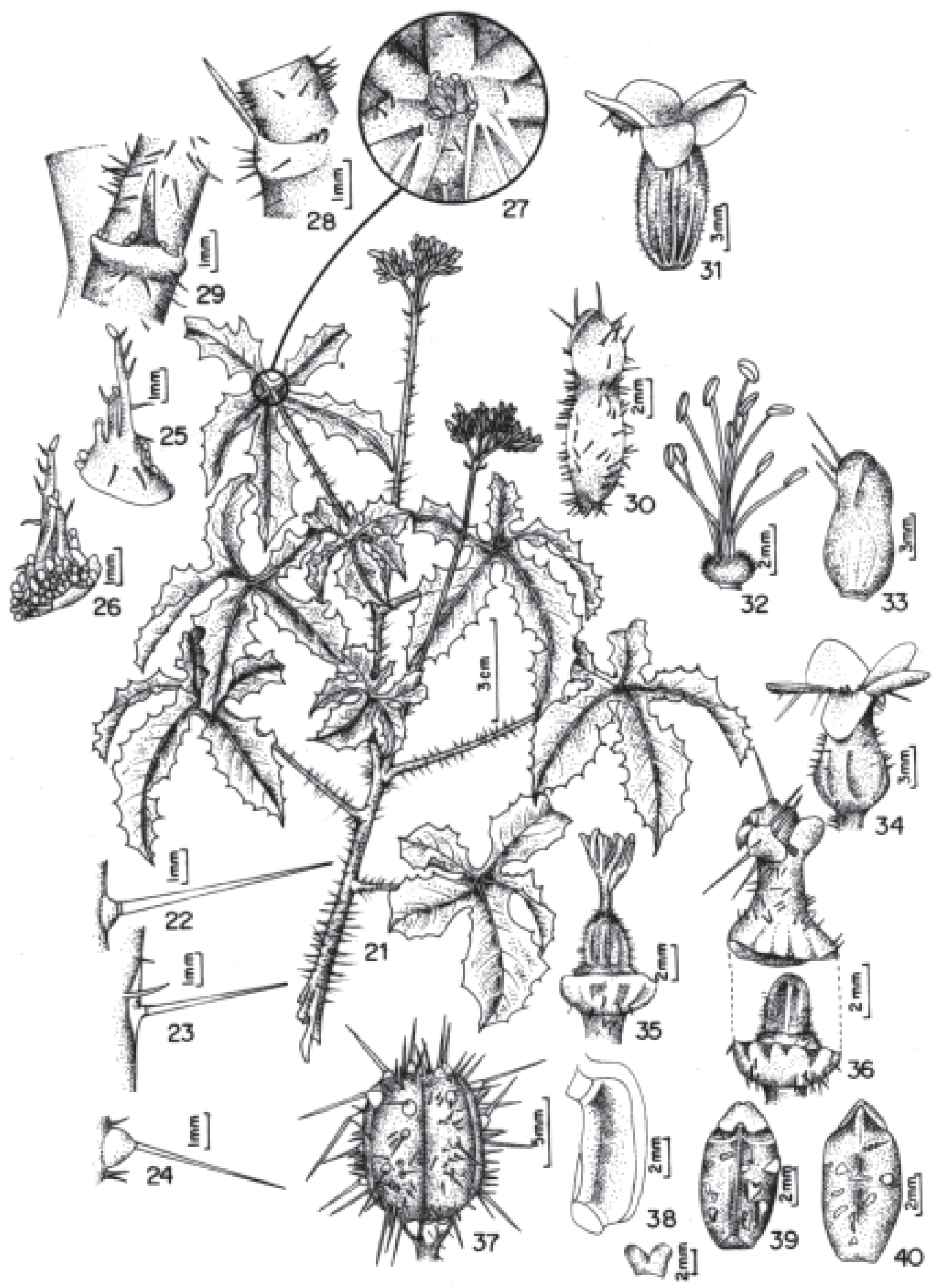

Figuras 21-40. Cnidoscolus loefgrenii (Pax \& K. Hoffm.) Pax \& K. Hoffm. 21. Ramo florido (Laurênio 1109 et al.). 22. Tricoma urticante aciculiforme no ramo. 23. Tricoma urticante aciculiforme no pecíolo. 24. Tricoma urticante aciculiforme com base turgescente. 25. Face externa da estípula. 26. Face interna da estípula. 27. Glândulas peciolares. 28. Bráctea em vista lateral. 29. Bráctea em vista frontal (Laurênio 504). 30. Botão masculino (Laurênio 1161, Tschá \& Costa e Silva). 31. Flor masculina (Laurênio 539 et al.). 32. Androceu (Laurênio 504). 33. Botão feminino (Laurênio 1306). 34. Flor feminina. 35. Gineceu. 36. Desprendimento do perianto da flor feminina. 37. Fruto. 38. Valva do fruto. 39. Semente, face ventral. 40. Semente, face dorsal (Laurênio 1161, Tschá \& Costa e Silva). 
fl. fr., Laurênio \& Lucena 1076 (PEUFR); Camutanga, 29/X/1998, fl., Laurênio et al. 1538 (PEUFR); Caruaru, 19/IV/1997, fl. fr., Laurênio et al. 484 (PEUFR); Custódia, 2/IV/1989, fl., Araújo s.n. (IPA 52179); Iati, 28/V/1997, fl. fr., Laurênio et al. 519 (PEUFR); Ibimirim, 27/I/1997, fl. fr., Rodal \& Nascimento 714 (PEUFR); Limoeiro, 12/V/1998, fl. fr., Laurênio \& Lucena 1050 (PEUFR); Mirandiba, 17/VII/1998, fl., Laurênio et al. 1118 (PEUFR); Parnamirim, 11/XII/1997, fl. fr., Miranda et al. 2899 (HST); Pesqueira, 30/VII/1998, fl. fr., Laurênio et al. 1162 (PEUFR); Petrolina, 25/XI/1983, fl., Fotius 3613 (IPA); Recife, 2/V/1997, fl. fr., Laurênio 505 (PEUFR); Sanharó, 30/VII/1998, fl. fr., Laurênio et al. 1161 (PEUFR); Santa Cruz da Baixa Verde, fl. fr., 16/VII/1998, Laurênio et al. 1106 (PEUFR); São Caetano, 11/I/1982, fl., Gallindo s.n. et al. (IPA 32069); Serra Talhada, fl. fr., 30/V/1997, Laurênio et al. 539 (PEUFR); Taquaritinga do Norte, 18/IV/1997, fl. fr., Laurênio et al. 469 (PEUFR); Triunfo, 16/VII/1998, fl. fr., Laurênio et al. 1110 (PEUFR); Venturosa, 1998, fl., Costa 26 (PEUFR); Vertentes, 18/IV/1997, fr., Laurênio et al. 466 (PEUFR).

Ocorre na Argentina (Lourteig \& O'Donell 1943) e Brasil (BA, CE, ES, PB, PR, PE, SP e SE). Em Pernambuco, é freqüente na zona das Caatingas, nas subzonas do Agreste e do Sertão e ocasional na zona da Mata (Fig. 168 a). No Sertão ocorre na região do Sertão Central e nos Chapadões Cretáceos, sendo comum na depressão sertaneja, e em maiores altitudes, como em Triunfo (900 m) e em Buíque (Chapada de São José $855 \mathrm{~m}$ ). Cresce em diferentes tipos de solo e ainda sobre afloramentos rochosos, em vegetação de caatinga e tipos vegetacionais afins. Na zona da Mata distribui-se em áreas perturbadas, e comumente é invasora. Floresce e frutifica de outubro a julho. Popularmente conhecida como "cansanção" (CE, PE e SE), "urtiga" ou "urtigabranca" (PE). Em Pernambuco o uso dos nomes "urtiga" ou "urtiga-branca" são mais comuns na zona da Mata, enquanto "cansanção" é mais difundido.

Cnidoscolus loefgrenii, juntamente com C. urens e C. urnigerus, faz parte de um grupo de espécies que variam de ervas a arbustos, com tricomas urticantes aciculiformes e latescentes, folhas palmatilobadas, glândulas numerosas e papiliformes na junção do pecíolo com a lâmina foliar, estames em número de 10, dispostos em 2 verticilos. Tais espécies distinguem-se entre si por características florais como forma e grau de união do perianto das flores estaminadas e pistiladas e pela disposição dos estames. Em C. loefgrenii o tubo do perianto das flores estaminadas é ligeiramente alargado na região mediana, estreitando-se levemente em direção às extremidades (Fig. 31), os filetes internos são unidos até aproximadamente a metade do seu comprimento e os filetes externos são livres (Fig. 32) ou todos os estames são ligeiramente unidos, formando uma coluna com até $0,5 \mathrm{~mm}$ compr., glabra ou ligeiramente velutina; em C. urnigerus o tubo é tipicamente urceolado (Fig. 138), os lobos são mais curtos que nas demais espécies e os estames são inteiramente livres (Fig. 139).

Nos herbários, a maioria das coleções da espécie estava erroneamente identificada como $C$. urens. Entretanto, estas espécies diferem principalmente quanto ao perianto das flores pistiladas, que é tubularhipocrateriforme a tubular-urceolado (Fig. 34) em C. loefgrenii, e com segmentos livres ou ligeiramente unidos em C. urens (Fig. 113 e 121).

3. Cnidoscolus obtusifolius Pohl, Pl. bras. icon. descr. 1: 62. 1827. Tipo: Brasil, Bahia, "Caxoiram, Villa Jacobina, et versus Malhada”, Martius s.n. (Holótipo, M, n.v.; fotografia do holótipo, IPA!).

Fig. 41-58

Arbusto, arvoreta ou árvore, 1-5 m alt. Tricomas urticantes aculeiformes $0,5-4 \mathrm{~mm}$ recobrindo os ramos; tricomas urticantes aciculiformes 2-6 mm compr. revestindo pecíolo, lâmina foliar, inflorescência, perianto e frutos. Ramos cilíndricos, cinzento-avermelhados, glabros a pubescentes nas extremidades. Estípulas $1-3 \times 1-2 \mathrm{~cm}$, em geral caducas, às vezes persistentes após a queda das folhas, irregularmente triangulares, margens glanduloso-papiladas, pubescentes a pubérulas. Pecíolo ausente ou com até $1,8 \mathrm{~cm}$ compr., cilíndrico, pubescente a velutino; glândula peciolar ausente. Lâmina foliar 3,3-11×2,2-8,5 cm, membranácea a cartácea, inteira, elíptica, oboval a orbicular, base aguda a cordada, ápice acuminado a arredondado, raramente mucronado, margem crenada com tricomas urticantes em cada ângulo, ou raramente inteira, ciliada e ondulada, face superior glabra a pubescente, tricomas urticantes sobre as nervuras primárias e secundárias; face inferior glabra a esparsamente velutina, tricomas urticantes restritos às nervuras primárias; nervação broquidódroma, raramente broquidódroma-craspedódroma, nervuras primárias 3 . Inflorescência 0,7-5×0,7-5 cm, imperfeitamente dicasial ou 3 dicásios dispostos em 2 níveis de ramificação, pubérula, híspido-pubescente a serícea; pedúnculo 0,5-2,5 cm compr.; brácteas e bractéolas 1,5-4 mm compr., triangulares, margens glanduloso-papiladas na porção basal, pubescentes. Flores estaminadas sésseis, posicionadas à partir do $2^{\circ}$ nível de ramificação; perianto $2 \mathrm{~cm}$ compr., tubular-campanulado ou tubularhipocrateriforme, branco-esverdeado, pubescente; tubo 5-10×4 mm; lobos 10-11×4-6 mm, elíptico-oblongos, ápice arredondado; estames 15-25, dispostos em 3-5 verticilos, parcialmente unidos em coluna de até $12 \mathrm{~mm}$ compr., glabra; filetes 3-13,2 mm; anteras $1-2 \times$ 


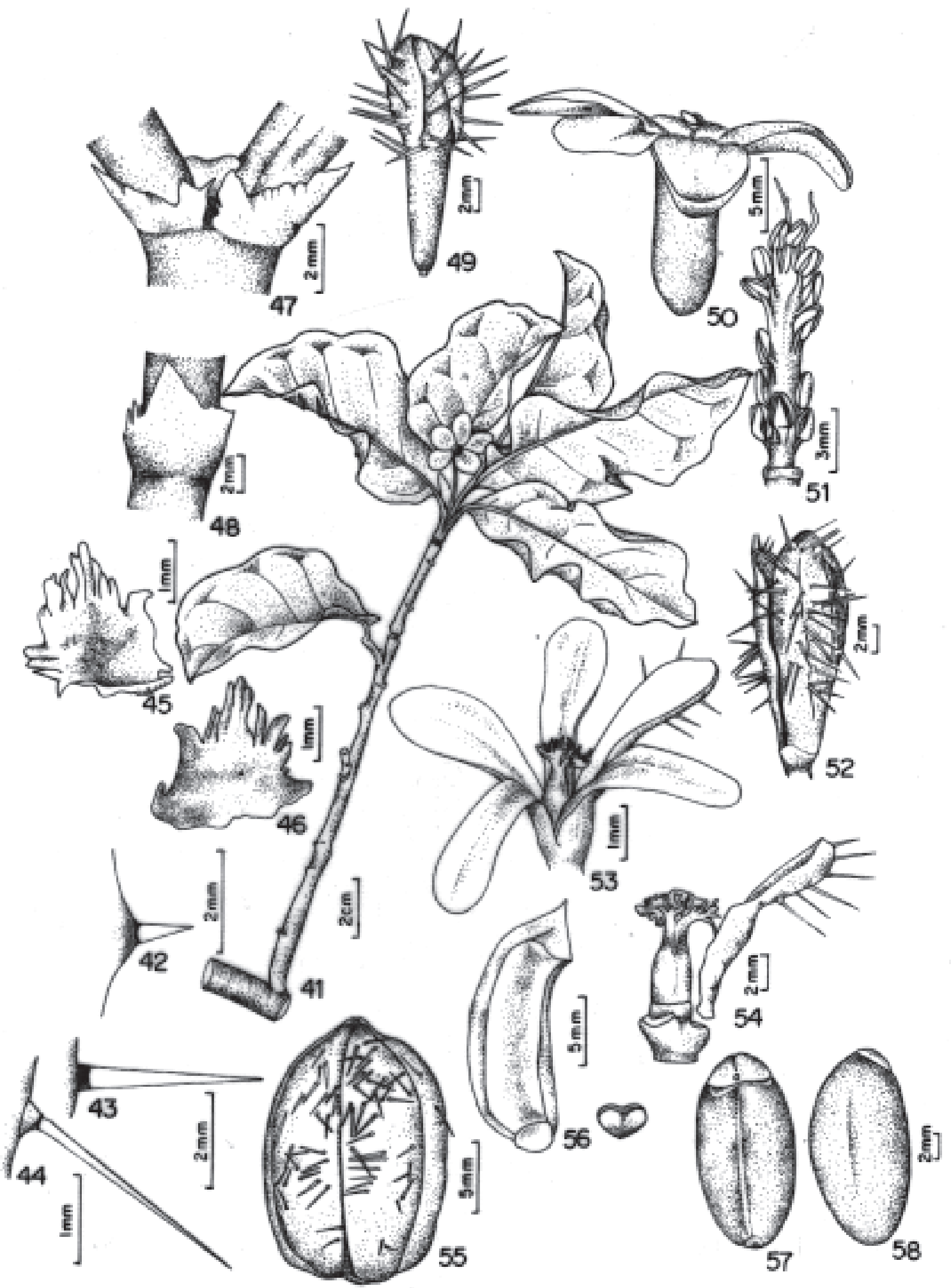

Figuras 41-58. Cnidoscolus obtusifolius Pohl. 41. Ramo florido (Laurênio 485 et al.). 42. Tricoma aculeiforme no ramo (Andrade 122). 43. Tricoma aciculiforme no pecíolo (Andrade 56). 44. Tricoma aciculiforme no fruto. 45. Face interna da estípula. 46. Face externa da estípula. 47. Brácteas em vista lateral. 48. Bráctea em vista frontal (Laurênio 1719 et al.). 49. Botão masculino (Brochado 184 \& Silva). 50. Flor masculina (Andrade 178). 51. Androceu (Laurênio 1719 et al.). 52. Botão feminino ((Laurênio 483). 53. Flor feminina (Andrade 178). 54. Desprendimento do perianto da flor feminina. 55. Fruto (Laurênio 398, Gomes \& Figueirêdo). 56. Valva do fruto (Laurênio 1719 et al.). 57. Semente, face ventral. 58. Semente, face dorsal (Andrade 178). 
0,25-1,2 mm, dorsifixas, oblongas; estaminódios 2-5, filiformes, $11 \mathrm{~mm}$ compr.; disco glandular $0,5 \times 1 \mathrm{~mm}$, anelar, ligeiramente lobado internamente, glabro. Botões florais estaminados obovóides, pistilados oblongos a ligeiramente ovóides. Flores pistiladas 1-3, posicionadas até o $2^{\circ}$ nível de ramificação; pedicelo $2 \mathrm{~mm}$ compr.; receptáculo/base persistente do perianto inconspícua; perianto $13 \mathrm{~mm}$ compr., branco, externamente esverdeado, segmentos livres, oblongos a ovais, pubescentes e urticantes, ápice arredondado; ovário ovóide, subcilíndrico em seção transversal, pubescente a híspido-seríceo; estiletes $4 \mathrm{~mm}$ compr., livres ou unidos na base, tetráfidos a multífidos, 12-36 ramos estigmatíferos; disco glandular anelar estriado, glabro. Fruto 1,4-2×1-1,5 cm, capsular loculicida e septicida, sub-piriforme, cilíndrico em seção transversal, velutino, urticante, ápice acuminado, base do estilete freqüentemente persistente. Semente 11-14,5x 6,9-8,1 mm, oblonga, côncava dorsalmente, convexa ou plana ventralmente, superfície marrom com máculas proeminentes mais escuras e/ou esbranquiçadas, base retusa, ápice agudo; carúncula 1,5×3 $\mathrm{mm}$.

Material examinado selecionado: BRASIL. Pernambuco: Bezerros, IX/1977. veg., Andrade-Lima 77-8306 (IPA); Buíque, 12/IV/1997, fl., Laurênio et al. 458 (PEUFR); Caruaru, 19/IV/1997, fl., Laurênio et al. 485 (PEUFR); Floresta, 21/IV/1989, fl., Rodal \& Ferraz 23 (IPA, PEUFR); Ibimirim, 27/I/1997, fl. fr., Rodal \& Nascimento 713 (PEUFR); Inajá, 29/V/1971, fl., Heringer et al. s.n. (IPA 19868); Petrolândia, 29/V/1997, fl. fr., Laurênio et al. 533 (PEUFR); Santa Cruz do Capibaribe, 29/VIII/1984, fl. fr., Pessoal do Ministério da Agricultura 1 (IPA); Sertânia, 8/XI/1986, Webster et al. 25622 (IPA).

Cnidoscolus obtusifolius está restrita ao Brasil, sendo registrada para Alagoas, Bahia, Espírito Santo, Pernambuco e Sergipe. Em Pernambuco ocorre na zona das Caatingas, nas subzonas do Agreste e Sertão (Fig. 168a). No sertão, está relacionada aos solos arenosos da região dos chapadões cretáceos, enquanto no Agreste predomina em solos argilosos ou argiloarenosos. Os espécimes no campo, quase sempre, estão em pequenos grupos isolados de 4 ou 5 indivíduos, exceto em Ibimirim e Buíque, onde formam extensos agrupamentos. Floresce e frutifica de novembro a agosto. Conhecida popularmente como "favela", "penão" e "urtiga-de-raposa" (PE), "favela-grande", "penon" e "quijila" (BA), "faveleira" (AL, SE), "orelha-de-onça" (PE, ES).

É reconhecida pelas folhas inteiras, elípticas, obovais a orbiculares, sem glândulas peciolares e ramos com tricomas urticantes aculeiformes. Não apresenta afinidades com as demais espécies de Pernambuco, no entanto é freqüentemente identificada como C. hamosus, espécie descrita para Minas Gerais e que também apresenta as folhas inteiras, tricomas aculeiformes nos ramos e aproximadamente o mesmo número de estames (15-25) dispostos em 3-5 verticilos. Entretanto, podem ser diferenciadas pelos tricomas urticantes incurvados, e pelas folhas ovais, com margem inteira, aparentemente não ondulada e com face inferior densamente vilosa em C. hamosus. Já em C. obtusifolius os tricomas urticantes são retos ou recurvados e as folhas elípticas, obovais a orbiculares, com margem geralmente crenada e ondulada e com face inferior glabra a esparsamente velutina.

4. Cnidoscolus oligandrus (Müll. Arg.) Pax, in Engl. \& Prantl., Nat. Pflanzenfam. ed. 2. 19c: 166. 1931.

Jatropha oligandra Müll. Arg. in Mart., Fl. bras. 11(2): 502. 1873. Tipo: Brasil, Rio de Janeiro, "Cantagallo", Peckolt 173 (Holótipo, BR, n.v.).

Fig. 59-78

Árvore 7-16 m alt.; tronco 20-50 cm diâm., rico em lenticelas e com ramos encurtados, cobertos por tricomas urticantes. Tricomas urticantes aciculiformes 2-8 mm compr. recobrindo esparsamente ramos, pecíolo, lâmina foliar e frutos. Ramos cilíndricos a subcilíndricos, acinzentados a cinzento-esverdeados, glabros a tomentosos, com ou sem tricomas urticantes adpressos. Estípulas $4 \times 2 \mathrm{~mm}$, caducas, triangulares a ovais, margens glanduloso-papiladas, pubescentes. Pecíolo (2-)5-24,5 cm compr., cilíndrico, sulcado quando seco, glabro a tomentoso, indumento creme a ferrugíneo, tricomas urticantes adpressos; glândulas peciolares 1-2, na junção com a lâmina, laminares com face interna multipapilada. Lâmina foliar (4,9-) 8,5-18,6× 7-25,5(-35) cm, membranácea a cartácea, 3-5-7palmatilobada, base cordada, ápice acuminado a cuspidado, margem inteira com pequenos apículos glandulares nas terminações das nervuras, face superior e inferior glabras a tomentosas, tricomas urticantes adpressos nas nervuras, nervação broquidódroma, nervuras primárias 3,5 ou 7 . Inflorescência 3,5-7,5× 5,5-17,5 cm compr., com 52-130 dicásios, em 5-8 níveis de ramificação, tomentosa; pedúnculo 1-2(-7) cm compr.; brácteas 1-2 mm compr., triangulares, margens glanduloso-papiladas na porção basal, glabras a tomentosas. Botões florais estaminados claviformes a obovóides, pistilados oblongo-ovóides. Flores estaminadas sésseis, posicionadas a partir do $5^{\circ}$ nível de ramificação; perianto $6,5-8 \mathrm{~mm}$ compr., tubularcampanulado, ligeiramente constricto no ápice do tubo, creme a creme-esverdeado, pubérulo a tomentoso, indumento ferrugíneo; tubo 4-6×2,2 mm; lobos 2-3 mm compr., ovais, ápice arredondado; estames 4-6, dispostos em 2-verticilos, parcialmente unidos em coluna 


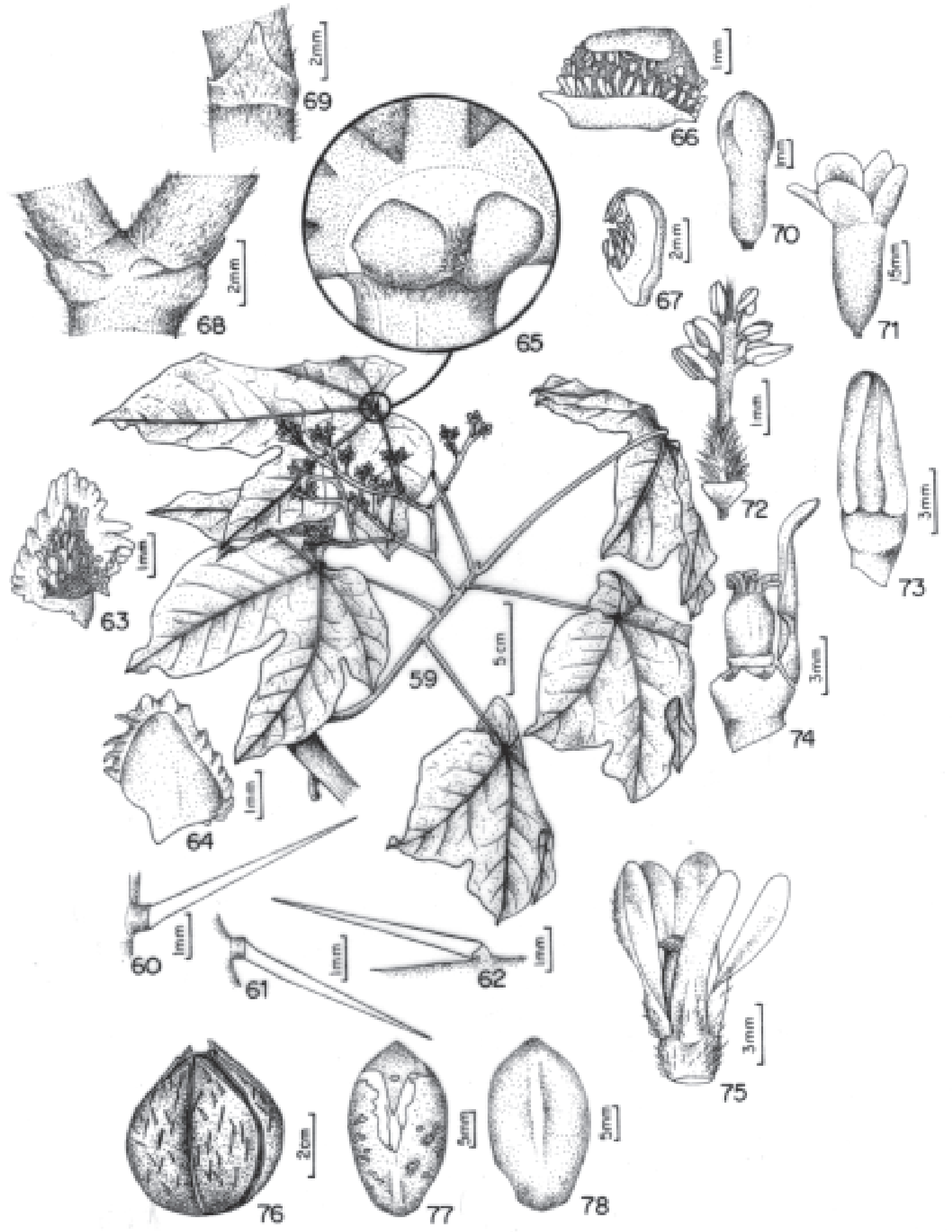

Figuras 59-78. Cnidoscolus oligandrus (Müll. Arg.) Pax. 59. Ramo florido (Laurênio 1088, Loiola \& Santos.). 60. Tricoma urticante aciculiforme no ramo. 61. Tricoma urticante aciculiforme no pecíolo. 62. Tricoma urticante aciculiforme no fruto (Laurênio $842 \&$ Santos). 63. Face externa da estípula. 64. Face interna da estípula. 65. Glândulas peciolares. 66. Face interna da glândula peciolar. 67. Glândula peciolar em corte longitudinal (Laurênio 1087, Loiola \& Santos). 68. Brácteas em vista lateral. 69. Bráctea em vista frontal. 70 . Botão masculino. 71. Flor masculina. 72. Androceu. 73. Botão feminino. 74. Desprendimento do perianto da flor feminina. 75. Flor feminina (Laurênio 1088, Loiola \& Santos). 76. Fruto. 77. Semente, face ventral. 78. Semente, face dorsal (Laurênio 950 et al.). 
1-2,5 mm compr., vilosa na base; filetes $1-5,8 \mathrm{~mm}$ compr.; anteras 0,6-1,2 compr., dorsifixas, oblongas; estaminódios 0-3, filiformes, raramente anterígeros, até 2,6 mm compr.; disco glandular 0,2-0,5×0,5-0,9 mm, anelar-cupuliforme, glabro. Flores pistiladas 6-14, posicionadas até o $3^{\circ}$ nível de ramificação; pedicelo 2-4 cm compr.; receptáculo/base persistente do perianto inconspícua; perianto 6-9,2 $\mathrm{mm}$ compr., segmentos livres, estreitamente oblongos, ápice arredondado, creme-esverdeados, pubérulo a tomentoso, indumento ferrugíneo; ovário ovóide, cilíndrico, tomentoso; estiletes 1-2 mm compr., tetráfidos, 12 ramos estigmatíferos; disco glandular $0,3 \times 2 \mathrm{~mm}$, anelar a anelar-cupuliforme, glabro. Fruto drupáceo, 4,2-5×3,5-4,5 cm, extremamente rígido, indeiscente, globoso, triangular em seção transversal, ápice agudo, superfície rugosa, pubérulo, tricomas urticantes, depressos; columela $2 \mathrm{~cm}$ compr. Semente $24 \times 12 \mathrm{~mm}$, oblonga a elipsóide, compressa dorsi-ventralmente, ligeiramente côncava na face ventral e convexa na dorsal, superfície marrom com máculas proeminentes marrom-claras, base e ápice agudos, não carunculada.

Material examinado selecionado: BRASIL. Pernambuco: Moreno, 17/IX/1998, fr., Laurênio et al. 1350 (PEUFR); São Lourenço da Mata, 13/III/1998, fr., Laurênio 842 \& Santos (PEUFR); Vicência, 17/XI/1962, fl. fr., Tavares 1141 (HST); Vitória de Santo Antão, 28/III/1998, fl. fr., Laurênio et al. 950 (PEUFR).

Exclusiva do Brasil (BA, MG, PE, RJ e SP [cultivada]). Em Pernambuco, ocorre na subzona da Mata Seca (Fig. 168a), em formações florestais abertas subcaducifólias com muitos afloramentos rochosos. Foram encontrados poucos indivíduos desta espécie nas localidades visitadas, sendo a maior população observada no engenho Jundiá, em Vicência. Floresce e frutifica de março a dezembro. Conhecida popularmente como "penon", "visgo-de-penon" ou "penão" (PE), "pinhão" (BA) e "ard'iabo" (MG).

É facilmente identificada pelas glândulas peciolares laminares, internamente multipapiladas, posicionadas na junção com a lâmina, estames em número reduzido (4-6), pelos frutos grandes e indeiscentes e sementes não carunculadas. No campo é reconhecida por ser a única espécie deste gênero de porte arbóreo que ocorre na zona da Mata. O número de estames encontrado (4-6) nos espécimes analisados foi inferior ao registrado para essa espécie (7-8) por Müller (1873) e Pax (1910); no entanto, as demais características conferem com a descrição original. A maioria das espécies de Cnidoscolus possui frutos capsulares loculicidas e septicidas, com deiscência explosiva e sementes carunculadas. Exceção é encontrada em C. oligandrus, que tem fruto drupáceo indeiscente, extremamente rígido e sementes não carunculadas. A deiscência explosiva, no entanto, não é considerada como o único fator de dispersão das sementes em Euphorbiaceae. De acordo com Webster (1994), sementes carunculadas são dispersas principalmente por formigas e frutos drupáceos por frugívoros. No presente estudo, de acordo com a observação de marcas deixadas no pericarpo de frutos coletados no chão e através de informações de moradores locais, presume-se que as cutias (Dasyprocta sp.) sejam os principais dispersores de sementes de C. oligandrus.

5. Cnidoscolus quercifolius Pohl, Pl. bras. icon. descr. 1: 62. 1827. Tipo: Brasil, Bahia, "inter Villam de Caxoeiram et Villa Jacobina”, Martius s.n. (Holótipo, BR, n.v.).

Cnidoscolus phyllacanthus (Müll. Arg.) Pax \& K. Hoffm. in Engl. \& Prantl, Nat. Pflanzenfam. ed. 2. 19c: 165. 1931.

Fig. 79-98

Arbusto, arvoreta ou árvore, 2-12 m alt. Tricomas urticantes aciculiformes 0,2-12 $\mathrm{mm}$ compr. recobrindo ramos, pecíolo, lâmina foliar, perianto e frutos. Ramos cilíndricos a subcilíndricos, cinzento-amarronzados a cinzento-avermelhados ou esverdeados quando jovens, glabros a pubérulos, frequentemente com ramos laterais encurtados, ricos em folhas e tricomas urticantes. Estípulas 0,5-2×1-5 mm, persistentes, glandulosofimbriadas, glabras. Pecíolo 0,3-3(-6,2) cm compr., cilíndrico a subcilíndrico, pubérulo; glândula peciolar ausente. Lâmina foliar (1-)3,5-10,4(-16)× (0,7-)1,6-8,2(-10,5) cm, cartácea a subcoriácea, em geral variavelmente pinatilobada a inteira oval a oblanceolada ou irregularmente triangular, base cuneada à cordada, às vezes assimétrica, ápice acuminado a agudo, às vezes arredondado, margem inteira, com apículos glandulares nas terminações das nervuras primárias e secundárias, faces superior e inferior glabras, tricomas urticantes geralmente restritos às nervuras primárias e secundárias ou ausentes, nervação broquidódroma ou mista broquidódroma-craspedódroma, nervuras primárias 3 . Inflorescência 1,5-4×2-6 cm, composta por 9-45 dicásios, dispostos em 4-5 níveis de ramificação, glabra a pubérula, raros tricomas urticantes; pedúnculo 0,6-4,2 cm compr.; brácteas 0,2-2(6) cm compr., triangulares a lanceoladas, sublineares a elípticas ou espatuladas foliáceas, ápice agudo a retuso-mucronadoglandular, margem lateralmente glanduloso-papilada na porção basal, glabra. Botões florais estaminados obovóides, pistilados oblongos. Flores estaminadas sésseis ou pedicelo até $4 \mathrm{~mm}$ compr., posicionadas a partir do $5^{\circ}$ nível de ramificação; perianto 5-10,3 mm compr., tubularhipocrateriforme a tubular-campanulado, branco, glabro 


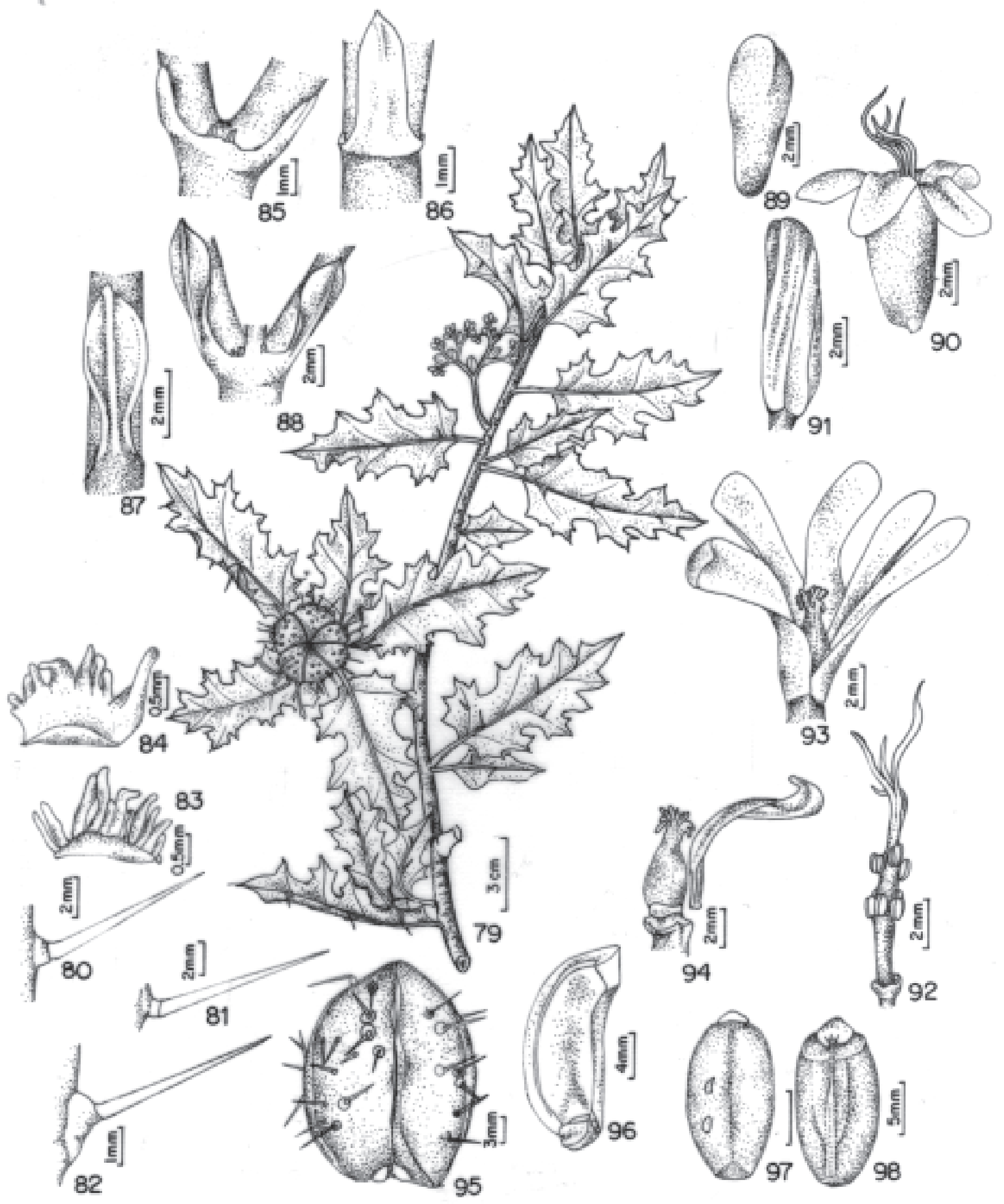

Figuras 79-98. Cnidoscolus quercifolius Pohl. 79. Ramo florido (Laurênio 1125 et al.). 80. Tricoma urticante aciculiforme no ramo. 81. Tricoma urticante aciculiforme no pecíolo (Figueiredo 529). 82. Tricoma urticante aciculiforme com base turgescente no fruto (Laurênio 412). 83. Face interna da estípula. 84. Face externa da estípula. 85. Brácteas em vista lateral. 86. Bráctea em vista frontal. 87. Brácteas em vista lateral. 88. Bráctea em vista frontal. 89. Botão masculino. 90. Flor masculina. 91. Androceu (Figueiredo 529). 92. Botão feminino. 93. Flor feminina. 94. Desprendimento do perianto da flor feminina (Tschá 1604). 95. Fruto. 96. Valva do fruto. 97. Semente, face dorsal. 98. Semente, face ventral (Laurênio 412). 
a raramente pubérulo ou pubescente, raros tricomas urticantes; tubo 3-8×1,5-4 mm; lobos 2-5 mm compr., obovais a oblongos, ápice arredondado; estames (8-)10(-14), dispostos em 2-verticilos, todos completamente unidos em coluna 6-7,4 mm compr., vilosa na base; filetes 0,5-7,5 $\mathrm{mm}$ compr.; anteras, $0,5-1 \times 0,5 \mathrm{~mm}$, oblongas; estaminódios 2-5, com (0,5-)2-8 mm compr., filiformes, freqüentemente anterígeros; disco glandular anelar-cupuliforme, 5-lobado ou, mais raramente 5 glândulas livres. Flores pistiladas sésseis, 3-7, até $3^{\circ}$ nível de ramificação; receptáculo/base persistente do perianto inconspícua; perianto 0,7-0,8 $\mathrm{mm}$ compr., branco, segmentos livres, estreitamente oblanceolados a oblongos, glabro, sem tricomas urticantes, ápice arredondado; ovário ovóide, cilíndrico ou ligeiramente anguloso em seção transversal, glabro; estiletes 0,5-1,8 mm compr., tetráfidos com 12 ramos estigmatíferos; disco glandular 0,2-1×1,5-2 mm anelar, às vezes achatado, glabro. Fruto cápsula loculicida e septicida, (10-)15-25×8-15,4 mm, piriforme, oblongoovóide, subcilíndrico a triangular em seção transversal, ápice agudo a acuminado, superfície rugosa, verde, glabra, columela 12-16,5 mm compr. Semente 11,4-13,5x 5,5-8 mm, elíptico-oblongóide a ovóide, côncava dorsalmente e convexa ventralmente, marrom-amareladas ou acinzentada, com ou sem máculas cinzento-escuras a cinzento-amarronzadas; carúncula 2-2,6×3-5 mm.

Material examinado selecionado: BRASIL. Pernambuco: Arcoverde, 24/I/1983, fl. fr., Campelo s.n. (UFMT 3350); Belém do São Francisco, 22/VI/1983, fl. fr., Coradin et al. 5926 (CEN); Buíque, 18/XI/1995, fl. fr., Figueirêdo et al. 234 (PEUFR); Cabrobó, 18/VII/1998, fl. fr., Laurênio et al. 1127 (PEUFR); Floresta 4/IV/1989, fr., Araújo s.n. (IPA 52202); Ibimirim, 16/II/1996, fr., Laurênio \& Rodal 313 (PEUFR); Lagoa Grande, 18/VII/1998, veg., Laurênio et al. 1130 (PEUFR); Mirandiba, 17/VII/1998, veg., Laurênio et al. 1120 (PEUFR); Orocó, 18/VII/1998, veg., Laurênio et al. 1126 (PEUFR); Petrolina, 28/I/1940, fl., Rambo s.n. (PACA 3556); Salgueiro, 17/VII/1998, fl. fr., Laurênio et al. 1125 (PEUFR); Santa Cruz do Capibaribe, 4/X/1984, fl. fr., Pessoal do Ministério da Agricultura s.n. (IPA 42347); Santa Maria da Boa Vista, 18/VII/1998, veg., Laurênio et al. 1128 (PEUFR); Serra Talhada, 29/XII/1976, fl. fr., Alves s.n. (UFP 5399); Sertânia, 16/VII/1977, fr., Lira \& Angélica s.n. (IPA 47192); Terra Nova, 4/IX/1986, fl., Lúcia et al. s.n. (PEUFR 11900).

Exclusiva do Brasil (BA, CE, MG, PB, PE, PI, RN e $\mathrm{SE})$ e da vegetação de caatinga. Em Pernambuco, ocorre na subzona do Sertão (Fig. 168b), em solos argilosos ou areno-argilosos. Floresce e frutifica de novembro a agosto. Conhecida popularmente como "cansanção"
(BA, MG, RN), "favela" (BA, PB, PI), "favela-decachorro" (PE), "favela-de-galinha" (PI), "favela-semespinho" (CE), "faveleira" (BA, PE, PI, RN, SE) e "faveleiro" (PE).

Apesar de apresentar grande variação na morfologia foliar, esta espécie é facilmente identificada pela ausência de glândulas peciolares, folhas pinatilobadas ou inteiras, tricomas do tipo urticante aciculiforme e pelos estames em número de (8-)10(-14), dispostos em dois verticilos, com filetes completamente unidos. Aparentemente não apresenta afinidade com as demais espécies de Pernambuco.

6. Cnidoscolus urens (L.) Arthur, Torreya 21: 11. 1921. Jatropha urens L., Sp. pl. 1007. 1753. Tipo: não localizado.

Fig. 99-127

Subarbusto ou arbusto 0,3-2,2(-4) m alt., caule algumas vezes intumescido na metade superior; tricomas urticantes aciculiformes $0,8-10 \mathrm{~mm}$ compr. nos ramos, pecíolo, lâmina foliar, inflorescência, perianto e fruto; Ramos cilíndricos, esparso a densamente velutinos ou glabrescente a pubescente. Estípulas 0,4-3×0,5-2,5 mm, persistentes, triangulares, margem e face interna glanduloso-papilada ou inteiramente glanduloso-fimbriada, glabras ou pubescentes. Pecíolo (1,8-)2,7-25,5 cm compr., esparso a densamente velutino ou híspidohirsuto; glândulas numerosas na junção do pecíolo com a lâmina, papiliformes. Lâmina foliar (1,3-)4,5-25,5× (2,1-)5,5-32 cm, membranácea a cartácea, 3-5-palmatilobada, base cordada a cuneada ou assimétrica, ápice arredondado a acuminado, margem denteada, inteira ou, mais raramente crenada, ciliada, com apículos glandulares em cada ponto de terminação das nervuras primárias e secundárias, face superior velutina ou esparsamente hirsuta a glabrescente, face inferior velutino-vilosa a esparsamente hirsuta a glabrescentes, nervação craspedódroma-broquidódroma, nervuras primárias 5,7 ou 9 . Inflorescência $1-9,2 \times 0,8-15 \mathrm{~cm}$, com 7-75 dicásios em 1-7 níveis de ramificação, velutina ou hirsuta; pedúnculo 0,7-12 cm compr.; brácteas 0,5-5(-7) $\mathrm{mm}$ compr., estreitamente triangulares a estreitamente obtruladas, margens glanduloso-papiladas na porção basal, pubescentes a velutinas ou hirsutas. Botões florais estaminados oblongos, ligeiramente constricto na fauce, pistilados oblongo-ovóides. Flores estaminadas sésseis, posicionadas a partir do $2^{\circ}$ nível de ramificação; perianto 9-21 $\mathrm{mm}$ compr., tubularhipocrateriforme, ligeiramente constricto no ápice do tubo, estreitando-se em direção à base, branco, externamente esverdeado, velutino ou escabroso a glabrescente; tubo 5-13×1,5-4 mm; lobos 3-8×2-4 mm, ovais a suborbiculares, elípticos a oblongos, às vezes 


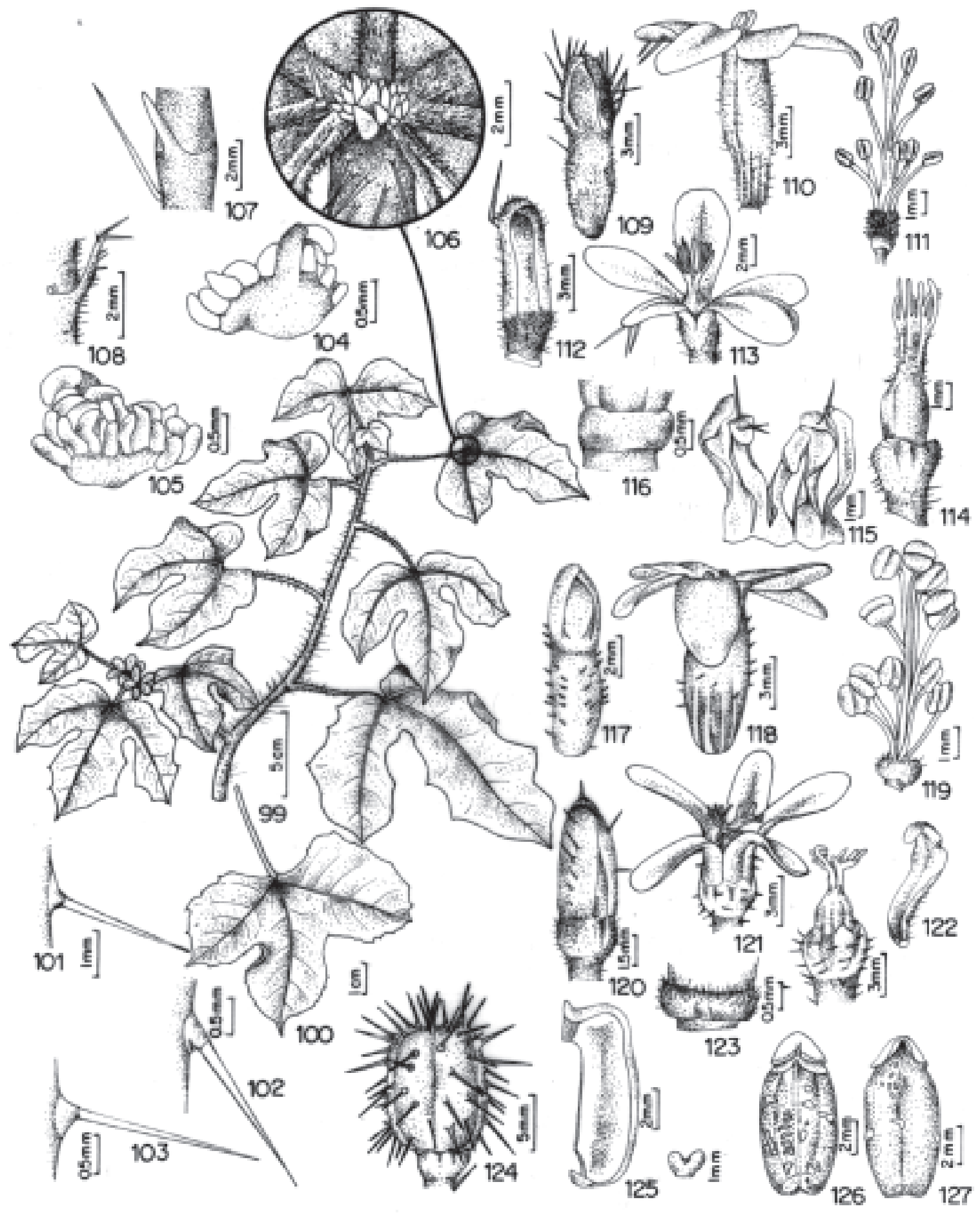

Figuras 99-127. Cnidoscolus urens (L.) Arthur. 99. Ramo florido do conjunto de populações 1 (Laurênio 1165, Tschá \& Costa e Silva). 100. Folha do conjunto de populações 2 (Laurênio 712). 101. Tricoma urticante aciculiforme no ramo (Laurênio 1094 \& R. Laurênio). 102. Tricoma urticante aciculiforme no pecíolo (Laurênio 1487 et al.). 103. Tricoma urticante aciculiforme no fruto (Laurênio 1453 et al.). 104. Face externa da estípula. 105. Face interna da estípula (Laurênio 1093 \& R. Laurênio). 106. Glândulas peciolares (Laurênio 1133 et al.). 107. Bráctea em vista lateral. 108. Bráctea em vista frontal. 109. Botão masculino (pop. 1) (Laurênio 704). 110. Flor masculina (pop. 1) (Laurênio 703). 111. Androceu (pop. 1) (Laurênio 704). 112. Botão feminino (pop.1) (Laurênio 546, Gomes \& Lucena). 113. Flor feminina (pop. 1). 114. Gineceu (pop. 1). 115. Perianto desprendido da flor feminina (pop. 1). 116. Disco glandular da flor feminina (pop. 1) (Laurênio 703). 117. Botão masculino (pop. 2). 118. Flor masculina (pop. 2). 119. Androceu (pop. 2) (Laurênio 1453 et al.). 120. Botão feminino (pop. 2) (Laurênio 1077 \& Gomes). 121. Flor feminina (pop. 2) (Laurênio 1453 et al.). 122. Desprendimento do perianto da flor feminina (pop. 2). 123. Disco glandular da flor feminina (pop. 2) (Laurênio 1487 et al.). 124. Fruto (Laurênio 1453 et al.). 125. Valva do fruto. 126. Semente, face ventral. 127. Semente, face dorsal (Laurênio 1487 et al.). 
assimétricos, ápice arredondado; estames férteis (8)10(13), em 2 verticilos; estames externos livres a unidos em coluna de até $0,5 \mathrm{~mm}$ compr., glabra à esparsamente velutina, ou inteiramente unidos em coluna de 0,5-2,2 mm compr., densamente vilosa; estames internos unidos até aproximadamente a metade do seu comprimento; filetes $(0,5-) 2-13 \mathrm{~mm}$ compr.; anteras 0,8-2×0,4-2 mm, oblongas, suborbiculares a elípticas; estaminódios 0-2, entre os estames do verticilo interno, filiformes ou ligeiramente espessados no ápice ou ainda com uma pequena antera estéril, até $11 \mathrm{~mm}$ compr.; disco glandular 0,2-2×0,4-2 mm, anelar, glabro ou pubescente a velutino. Flores pistiladas $1-9$, posicionadas até o $3^{\circ}$ nível de ramificação; pedicelo 1-7 mm compr.; receptáculo/base persistente do perianto fortemente denteado; perianto 5-8,5×1,5-3,5 mm, segmentos livres, ou raramente unidos até $2,5 \mathrm{~mm}$, inteiramente branco ou esverdeado, externamente velutino ou escabroso, ápice arredondado; ovário ovóide, 3- ou 6-anguloso em seção transversal, glabro a pubescente ou velutino a viloso; estiletes 1,5-5,2 $\mathrm{mm}$ compr., tetráfidos ou multífidos, (10)12-18 ramos estigmatíferos, geralmente glabros; disco glandular 0,5-1(-1,5)×1-2,5 mm, anelar, glabro ou pubescente. Cápsula 7-11×7-10 mm, loculicida e septicida, deiscência fortemente explosiva, globoso ou subgloboso, ápice retuso e ligeiramente apiculado, híspido-pubescente, tricomas urticantes, geralmente com base translúcida e turgescente; columela 6-9 $\mathrm{mm}$ compr. Semente 6-8,5×3,2-5 mm, largamente elíptica a elíptica, côncava dorsalmente, convexa ou plana ventralmente, com uma linha central depressa, superfície com máculas proeminentes marrons, marrom-acinzentadas ou enegrecidas, quando imatura amarelada; carúncula $(1,5) 2-3 \times 1-2,3 \mathrm{~mm}$.

Material examinado selecionado: BRASIL. Pernambuco: Arcoverde, 23/III/1983, fl. fr., Gallindo s.n. et al. (IPA 42320); Arquipélago de Fernando de Noronha, 1/VI/1993, fl. fr., Miranda et al. 883 (PEUFR); Barra de Guabiraba, 20/X/1998, fl. fr., Laurênio \& Lucena 1528 (PEUFR); Bonito, 23/VII/1998, fl. fr., Laurênio et al. 1137 (PEUFR); Cabo de Santo Agostinho, 10/VII/1998, fl. fr., Laurênio et al. 1103 (PEUFR); Camutanga, 29/X/1998, fl. fr., Laurênio et al. 1542 (PEUFR); Carpina, 10/VIII/1998, fl. fr., Laurênio et al. 1188 (PEUFR); Caruaru, 12/V/1998, fl. fr., Laurênio \& Lucena 1051, 1052, 1053 (PEUFR); Ferreiros, 29/X/1998, fl., Laurênio et al. 1541 (PEUFR); Goiana, 16/VI/1998, fl., Laurênio et al. 1077, 1078 (PEUFR); Igarassu, 6/IV/1983, fl., Barreto \& Chiappetta 11 (IPA); Ipojuca, 11/IV/1998, fl. fr., Laurênio \& Lucena 1037 (PEUFR); Itamaracá, 22/III/1998, fl., Laurênio \& Lucena 916 (PEUFR); Itambé, 14/IX/1997, fl. fr., Lucena \& Lucena 332 (PEUFR); Maraial, 13/X/1996, fl. Siqueira-
Filho et al. 141 (UFP); Moreno, 17/IX/1998, fl. fr., Laurênio et al. 1354 (PEUFR); Paudalho, 11/VIII/1998, fl. fr., Laurênio et al. 1197 (PEUFR); Paulista, 6/VII/1998, fl. fr., Laurênio \& R. Laurênio 1098 (PEUFR); Poção, 30/VII/1998, fl. fr., Laurênio et al. 1167 (PEUFR); Pombos, 23/VII/1998, fl., Laurênio et al. 1133 (PEUFR); Quipapá, 12/I/1994, fl. fr., Miranda 1184 (PEUFR); Recife, 19/III/1998, fl. fr., Laurênio et al. 907 (PEUFR); Rio Formoso, 7/X/1998, fl. fr., Laurênio et al. 1498 (PEUFR); Sairé, s.d., fr., Oliveira 17 (UFP); São Benedito do Sul, 28/I/1999, fl. fr., Lucena et al. 713 (PEUFR); São José da Coroa Grande, 7/X/1998, fl. fr., Laurênio et al. 1493 (PEUFR); São Lourenço da Mata, VI/1917, fr., Pickel 23 (IPA); São Vicente Férrer, 24/VIII/1998, fl. fr., Ferraz, Laurênio \& Bispo 416 (PEUFR); Sirinhaém, 11/IV/1998, fl. fr., Laurênio \& Lucena 1047 (PEUFR); Tamandaré, 7/X/1998, fl. fr., Laurênio et al. 1495 (PEUFR); Vicência, 5/XI/1997, fl. fr., Laurênio et al. 645 (PEUFR); Vitória de Santo Antão, 6/III/1999, fl. fr., Laurênio \& Gomes 1549 (PEUFR).

Cnidoscolus urens tem a distribuição mais ampla do gênero, ocorrendo desde a porção oriental do México até a Argentina (Burger \& Huft 1995); no Brasil, no Nordeste (AL, BA, PB, PE, PI, RN e SE), Sudeste (ES, MG e RJ) e Centro-Oeste (DF). Em Pernambuco ocorre em uma faixa contínua deste a zona do Litoral até a subzona do Agreste (Fig. 168b) e a partir daí torna-se esporádica, restringindo-se às áreas com maior umidade. Cresce em áreas perturbadas, sendo comum em clareiras e bordas de mata, sobre afloramentos rochosos, em solos argilosos ou arenosos do litoral, ou ainda sobre guano em Fernando de Noronha. Floresce e frutifica o ano inteiro. Conhecida popularmente como "cansanção" (BA, PB, PE, PI), "cansanção-branco" (PI), "urtiga" (PB, PE, $\mathrm{PI})$ ou "urtiga-branca" (PB, PE, RN).

Esta espécie pode ser reconhecida pelo seguinte conjunto de características: numerosas glândulas papiliformes na junção do pecíolo com a lâmina, perianto das flores pistiladas com segmentos livres ou raramente unidos por até $2,5 \mathrm{~mm}$ compr. e estames (8-)10(-13) em dois verticilos, com filetes externos livres, ou todos unidos formando uma coluna com até 2,2 mm compr., glabra, híspida ou densamente vilosa.

Em Pernambuco, dois conjuntos de populações com características morfológicas particulares, distribuição geográfica e aspectos ecológicos distintos podem ser enquadradas sob a circunscrição de Cnidoscolus urens de Müller (1866; 1873) e Pax (1910). O conjunto 1 apresenta folhas geralmente cartáceas, profundamente lobadas e com lobos mais estreitos e o androceu com todos os filetes unidos na base, formando uma coluna com até 2,2mm compr., densamente vilosa (Fig. 111); distribui-se desde a zona da Mata até o Agreste, em solos 
argilosos ou sobre afloramentos rochosos. O conjunto 2 , possui folhas membranáceas, geralmente com lobos mais largos e menos profundos e o androceu filetes externos livres ou com todos os filetes unidos na base formando uma coluna muito curta de até $0,5 \mathrm{~mm}$ compr. (Fig. 119), glabra ou ligeiramente híspida. Restrita à zona do litoral, crescendo em solos arenosos e não é registrada sobre afloramentos.

Cnidoscolus urens apresenta afinidades com C. loefgrenii e C. urnigerus. As duas diferenciam-se de C. urens por possuírem perianto das flores pistiladas com segmentos unidos, formando um tubo. Especialmente o conjunto de populações 2 de Cnidoscolus urens parece relacionar-se com $C$. loefgrenii, assemelhando-se principalmente pelo hábito, forma geral das folhas, forma do perianto das flores estaminadas e, sobretudo, disposição dos estames.

7. Cnidoscolus urnigerus (Pax) Pax in Engl. \& Prantl, Nat. Pflanzenfam. ed. 2. 19c: 166. 1931.

Jatropha urnigera Pax in Engl., Pflanzenr. IV. 147, I: 104. 1910. Tipo: Brasil, Bahia, Caldeirão, Ule 7041 (Holótipo, B, n.v.).

Fig. 128-147

Subarbusto ou arbusto 0,8-1,5 m alt.; tricomas urticantes 2-9,5 mm compr. nos ramos, pecíolos, lâminas foliares, inflorescências, periantos e frutos. Ramos esparso a densamente pubérulos a velutinos. Estípulas 1-2,5×1-1,5 mm, persistentes, triangulares, margem e face interna glanduloso-papilada ou inteiramente glanduloso-fimbriada, glabras a pubescentes. Pecíolo 6,8-13,2 cm compr., esparso a densamente pubérulo a velutino; glândulas numerosas na junção do pecíolo com a lâmina, papiliformes. Lâmina foliar 4,2-11,5×7,5-15,5 cm, membranácea, 3-5 palmatilobada, nervuras base sagitada a cordada, margem crenada a denteada ou raramente inteira, ciliada, com apículos glandulares em cada ponto de terminação das nervuras primárias e secundárias, face inferior esparso a densamente pubérula a velutina, face superior pubescente a pubérula, nervação craspedódroma-broquidódroma ou inteiramente craspedódroma, primárias 5,7 ou 9 . Inflorescência 2,4-3,1×3,5-4,3 cm, com 21-30 dicásios, em 3-5 níveis de ramificação, esparso a densamente velutina; pedúnculo 6-9,7 cm compr.; brácteas 1-3 mm compr., estreitamente triangulares a lanceoladas, papilas glandulosas lateralmente próximo a base, pubescentes a velutinas. Botões florais estaminados e pistilados ovóides. Flores estaminadas sésseis, posicionadas a partir do $3^{\circ}$ nível de ramificação, perianto 6-8 $\mathrm{mm}$ compr., tubularurceolado, branco, às vezes externamente esverdeado, velutino; tubo 4,5-5,5×3-3,5 mm; lobos 1,5-1-1,5 mm, largamente ovais, ápice arredondado; estames férteis 10 , livres, em dois verticilos pouco diferenciados, filetes 1,5-3 mm compr., anteras 1-1,4×0,5-1 mm, oblongas a elípticas ou suborbiculares; estaminódios 2, filiformes, ca. de 0,5mm compr.; disco glandular 0,4-2×0,5-1 mm, anelar. Flores pistiladas 3-8, posicionadas até o $3^{\circ}$ nível de ramificação; pedicelo 1-4 mm compr.; receptáculo/ base persistente do perianto inteiro ou ligeiramente denteado; perianto 6-7 $\times 5-6 \mathrm{~mm}$, tubular-urceolado, velutino; tubo $4 \times 6 \mathrm{~mm}$, lobos 2-3×1-2 mm, ovais, ápice arredondado; ovário oblongo, pubescente a velutino; estiletes 3-4 mm compr., bífidos ou tetráfidos, glabro; disco glandular $1 \times 2 \mathrm{~mm}$, anelar, glabro. Cápsula 8,3-9,9×7,4-8,3 mm, loculicida e septicida, deiscência fortemente explosiva, oblonga, híspido-hirsuta, ápice retuso, apiculado, superfície rugulosa, quando seca, tricomas urticantes com ou sem base turgescente; columela $8 \mathrm{~mm}$ compr.. Semente $8-9 \times 4 \mathrm{~mm}$, elípticooblonga, côncava dorsalmente, plana ventralmente com linha central proeminente, marrom com máculas proeminentes enegrecidas, base truncada, ápice agudo; carúncula 1,8-2×3 $\mathrm{mm}$.

Material examinado: BRASIL. Pernambuco: Araripina, 12/XII/1997, fl. fr., Miranda et al. 2913 (HST).

Restrita ao Brasil (BA, PE e PI). Em Pernambuco só foi registrada para o município de Araripina (Fig. 168b). Floresce e frutifica em dezembro. Conhecida popularmente como "cansanção" (BA, PE).

Cnidoscolus urnigerus é facilmente reconhecida pelo perianto tubular-urceolado nas flores estaminadas e pistiladas e pelos estames completamente livres. A espécie tem afinidades com C. urens e C. loefgrenii, porém estas apresentam pelo menos os estames do verticilo interno unidos. Além disto, apenas C. urnigerus tem as flores estaminadas e pistiladas tubular-urceoladas.

8. Cnidoscolus vitifolius (Mill.) Pohl, Pl. bras. icon. descr. 1: 62. 1827.

Jatropha vitifolia Mill., Gard. Dict. ed. 8. n.5. 1768.

Tipo: não localizado.

Fig. 148-167

Arbusto ou arvoreta 0,6-4m alt.; tricomas urticantes aciculiformes 1-10 mm compr. nos ramos, pecíolos, lâminas foliares, inflorescências e frutos. Ramos cilíndricos, tomentosos. Estípulas 1-5,5(-8)×1-2,5 mm, persistentes, triangulares a estreitamente obtruladas, margem e face interna glanduloso-papiladas,. Pecíolo 1,3-17 mm compr., subcilíndrico, velutino a tomentoso; glândulas no ápice do pecíolo, numerosas, em 1 ou 2 conjuntos, papiliformes. Lâmina foliar 3,8-20,5x 4,2-23 cm, cartácea, 3-5-7-palmatilobada, base sagitada, ápice arredondado a acuminado, margem denteada, às vezes ciliada, com tricomas urticantes, face superior 


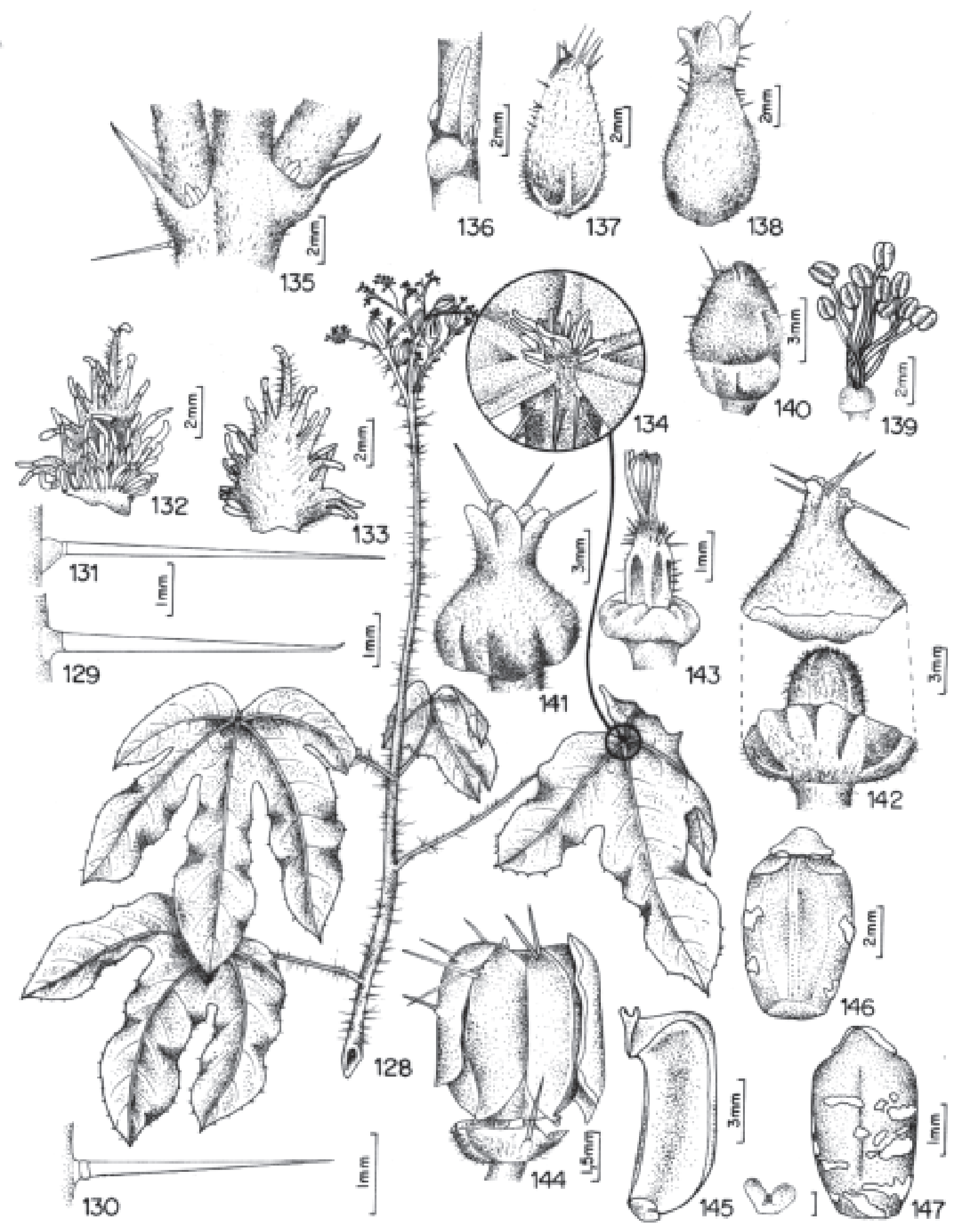

Figuras 128-147. Cnidoscolus urnigerus (Pax) Pax. 128. Ramo florido (Laurênio et al. 1701 et al.). 129. Tricoma urticante aciculiforme no ramo. 130. Tricoma urticante aciculiforme no pecíolo. 131. Tricoma urticante aciculiforme no fruto. 132. Face interna da estípula. 133. Face externa da estípula. 134. Glândulas peciolares. 135. Brácteas em vista lateral. 136. Bráctea em vista frontal. 137. Botão masculino. 138. Flor masculina. 139. Androceu (Laurênio 1701 et al.). 140. Botão feminino (Miranda \& Esteves 123). 141. Flor feminina. 142. Desprendimento do perianto da flor feminina (Laurênio 1701 et al.). 143. Gineceu (Allem 2923, Werneck \& Webster). 144. Fruto. 145. Valva do fruto. 146. Semente, face ventral. 147. Semente, face dorsal (Laurênio 1701 et al.). 


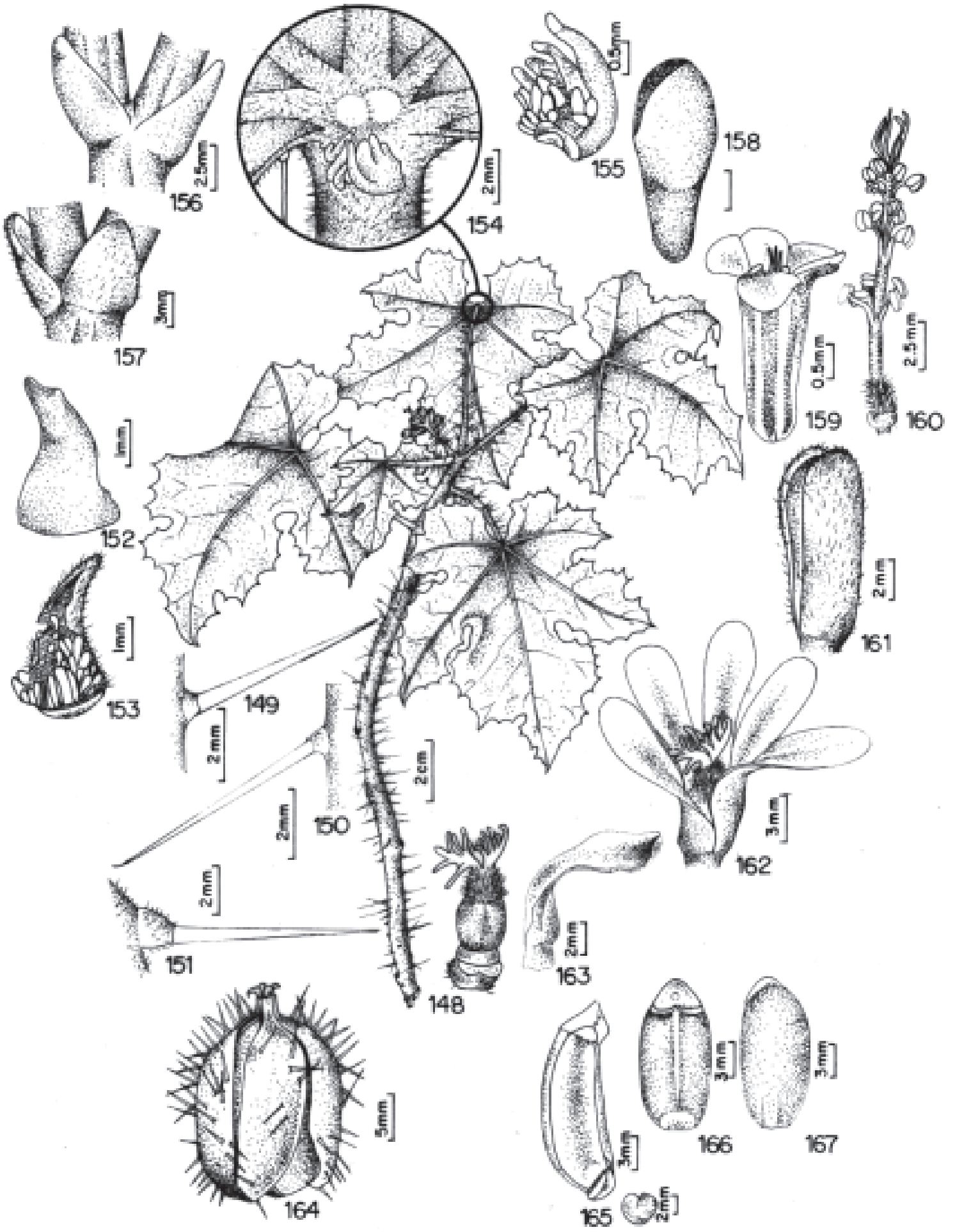

Figuras 148-167. Cnidoscolus vitifolius (Mill.) Pohl. 148. Ramo florido (Laurênio 1122). 149. Tricoma urticante aciculiforme no ramo. 150. Tricoma urticante aciculiforme no pecíolo (Loiola 591). 151. Tricoma urticante aciculiforme no fruto (Laurênio 1229). 152. Face externa da estípula. 153. Face interna da estípula. 154. Glândulas peciolares. 155. Face interna das glândulas peciolares. 156. Brácteas em vista lateral. 157. Brácteas em vista frontal (Laurênio 1228). 158. Botão masculino (Loiola 591). 159. Flor masculina (Laurênio 691). 160. Androceu (Laurênio 433). 161. Botão feminino (Loiola 591). 162. Flor feminina. 163. Gineceu mostrando desprendimento do perianto (Laurênio 1228). 164. Fruto (Laurênio 1231). 165. Valva do fruto. 166. Semente, face ventral. 167. Semente, face dorsal (Laurênio 1229). 
glabra a velutina, face inferior velutino-tomentosa, raramente glabra, nervação craspedódroma-broquidódroma, primárias 5, (6) ou 7. Inflorescência composta por 6-39 dicásios dispostos em 3-6 níveis de ramificação, $1,5-7,5 \times 2,3-10,5(-13,5) \mathrm{cm}$, tomentosa a velutina; pedúnculo $0-7 \mathrm{~cm}$ compr.; brácteas $2,5-8 \mathrm{~mm}$, inteiras, triangulares a raramente linear-lanceoladas ou trilobadas, margens glanduloso-papiladas ou não, pubescentes a densamente tomentosas. Botões florais estaminados obovóides, pistilados oblongos. Flores estaminadas sésseis, posicionadas a partir do $3^{\circ}$ nível de ramificação; perianto (11,5-)14,5-20 mm compr., tubular-infundibuliforme a tubular-campanulado, branco ou creme, pubérulo a velutino, raramente tricomas urticantes; tubo (5-)7,5-14×3-8 mm; lobos (2,5-)5-7×2,5-5,5 mm, ovais, orbiculares, ápice arredondado ou raramente agudo; estames férteis 11-20, em 3 ou 4 verticilos, unidos em coluna, 7,5-13,5 mm compr., vilosa na base; filetes $(1,5) 3,5-12(-15) \mathrm{mm}$ compr.; anteras 0,7-1,7x 0,5-1,2 mm, oblongas ou suborbiculares; estaminódios 2-5, filiformes, raramente anterígeros, (8,5-)11-16 mm compr.; disco glandular 0,4-1×0,6-1,5 mm, anelar, com estrias longitudinais, freqüentemente lobado nos botões. Flores pistiladas 1-7, posicionadas até o $4^{\circ}$ nível de ramificação, sésseis ou pedicelo, até $3 \mathrm{~mm}$ compr.; receptáculo/base persistente do perianto inconspícuo; perianto 9-13×3-4 mm, branco ou creme, com segmentos inteiramente livres, oblanceolados, obovaloblanceolados, às vezes ligeiramente assimétricos, pubérulo a velutino, sem tricomas urticantes, ápice arredondado; ovário piriforme, fortemente acuminado, pubérulo a velutino, geralmente não urticante; estiletes 2,2-3 mm compr., livres ou ligeiramente unidos na base, multífidos, 15-35 ramos estigmatíferos, glabro a pubescente; disco glandular 0,5-1×1,7-2,5 $\mathrm{mm}$, anelar ou 5-lobado. Cápsula (12-)15-23×8,5-14,4 mm, loculicida e septicida, piriforme, oblonga a ovóide, ápice acuminado, superfície rugosa, verde, tomentosa; columela 12-16,5 mm compr. Semente 10,3-13,9x 6,4-7mm, elíptico-oblonga a ovóide, côncava dorsalmente e convexa ventralmente, marrom ou acinzentada, com máculas cinzento-escuras a cinzentoamarronzadas, base arredondada, ápice agudo a arredondado; carúncula 2-2,5×4-5 mm.

Material examinado selecionado: BRASIL. Pernambuco: Araripina, 14/IV/1965, fl., Sobrinho 40 (HST); Buíque, 5/XII/1996, fl., Laurênio et al. 433 (PEUFR); Ibimirim, 27/I/1997, fl., Rodal \& Nascimento 712 (PEUFR); Inajá, 24/III/1983, fl., Gallindo et al. s.n. (IPA 42324); Ipubi, 1/IX/1998, fl. fr., Laurênio et al. 1262 (PEUFR); Mirandiba, 17/VII/1998, fl. fr., Laurênio et al. 1122 (PEUFR); Ouricuri, 10/III/1982, fl., Lima et al. 45 (PEUFR, IPA); Sertânia, 8/XI/1986, fl., Webster et al. 25621 (IPA); Tupanatinga, 7/X/1984, fl., Gallindo et al. s.n. (IPA 42338); Trindade, 26/IV/1983, fl., Gallindo et al. s.n. (PEUFR 7374, IPA 42312 e 42473).

Ocorre na Argentina (Pax 1910; Lourteig \& O’Donnel 1943) e Brasil (BA, CE, MA, MT, MS, PE e PI). Em Pernambuco, está distribuída na zona das Caatingas, subzona do Sertão (Fig. 168b) ocorrendo, sobretudo próximo aos chapadões cretáceos, como na chapada do Araripe e na bacia sedimentar do Jatobá. Predomina em solos arenosos ou areno-argilosos. Floresce e frutifica de setembro a abril. Conhecida popularmente como "cansanção" (CE, MA, MT, MS e $\mathrm{PE})$, "favela" (PE) e "urtiga" (CE).

Cnidoscolus vitifolius é reconhecida principalmente pelo seguinte conjunto de características: ramos com tricomas urticantes aciculiformes, folhas lobadas, glândulas do ápice do pecíolo numerosas, multipapiladas, distribuídas em 1 ou 2 conjuntos e androceu com 11-22 estames, dispostos em 3-4 verticilos, unidos em coluna densamente vilosa na base.

Apresenta afinidades com Cnidoscolus bahianus, da qual distingue-se principalmente pelos tricomas urticantes aciculiformes nos ramos, enquanto em C. bahianus são aculeiformes.
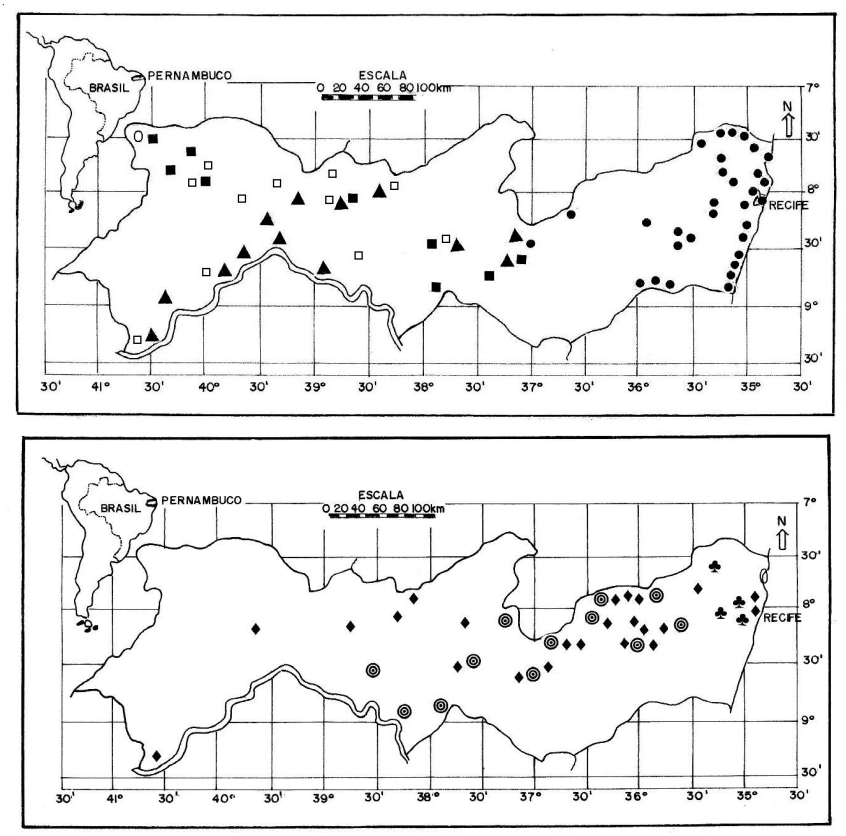

Figuras 168. a. Distribuição de Cnidoscolus loefgrenii (Pax \& K. Hoffm.) Pax \& K. Hoffm. (•), C. oligandrus (Müll. Arg.) Pax (\$) e C. obtusifolius Pohl (๑) no Estado de Pernambuco. b. Distribuição geográfica de Cnidoscolus urens (L.) Arthur $(\bullet), C$. bahianus (Ule) Pax \& K. Hoffm. ( $\square)$, C. quercifolius Pohl (\), C. urnigerus (Pax) Pax (*) e C. vitifolius (Mill.) Pohl (ロ) no Estado de Pernambuco. 


\section{Agradecimentos}

Aos curadores dos herbários que emprestaram suas exsicatas para a realização desse estudo; ao Conselho de Desenvolvimento Científico e Tecnológico (CNPq), pela concessão da bolsa de estudo ao primeiro autor; à Erilze Brito, pela finalização das figuras.

\section{Referências bibliográficas}

Andrade-Lima, D. 1957. Estudos Fitogeográficos de Pernambuco. Arquivos do Instituto de Pesquisas Agronômicas 5: 305-341.

Andrade-Lima, D. 1961. II Tipos de floresta de Pernambuco. In: Andrade-Lima. D. de.. Anais da Associação dos Geógrafos Brasileiros 12: 69-85.

Bezerra, G.E. 1972. Favela - seu aproveitamento como forrageira. Boletim Técnico 30: 71-87.

Bondar, G. 1942. Penão - Cnidoscolus marcgravii Polh - novo recurso oleífero da Bahia. Boletim do Instituto Central de Fomento Econômico da Bahia 12: 1-16.

Braga, R. 1976. Plantas do nordeste brasileiro - especialmente do Ceará. Mossoró, Editora Mossoró.

Breckon, G.J. 1979. Studies in Cnidoscolus (Euphorbiaceae) I. Jatropha tubulosa, J. liebmannii and allied taxa from central México. Brittonia 31: 125-148.

Burger, W. \& Huft, M. 1995. Family 113 Euphorbiaceae. In: Burger, W. \& Huft, M. Flora Costaricensis. Fieldiana 36: 1-169.

Castells, A.R.C.; Ormond, W.T. \& Braconi, A. 1984. Contribuição ao estudo da biologia de Jatropha gossypifolia L. (Euphorbiaceae). I-Laticíferos e glândulas. Revista Brasileira de Biologia 44: 149-158.

Croizat, L. 1943. New or critical Euphorbiaceae of Brazil. Tropical Woods 76: 11-14

Hans, A.S. 1973. Chromosomal conspectus of the Euphorbiaceae. Taxon 22: 591-636.

Hickey, L.J. 1973. Classification of the architeture of dicotyledonous leaves. American Journal of Botany 60: 17-33.

Holmgren, P.K.; Holmgren, N.H. \& Barnett, L.C. 1990. Index Herbariorum. Part I: the herbaria of the world. New York, New York Botanical Garden.

Ingram, J. 1957. Notes on the cultivated Euphorbiaceae 1. The flowers of the Euphorbiaceae 2. Cnidoscolus and Jatropha. Baileya 5: 107-117.

Lawrence, G.H.M. 1973. Taxonomia das plantas vasculares. v.2. Lisboa, Fundação Calouste Gulbenkian.

Lima, J.L.S. 1998. Plantas forrageiras das caatingas - usos e potencialidades. Petrolina, EMBRAPA.

Lourteig, A. \& O'Donell, C.A. 1943. Euphorbiaceae Argentinae Phyllantheae, Dalechampieae, Cluytieae, Manihoteae. Lilloa 9: 77-173.

Lutz, O. 1914. The poisonous nature of the stinging hairs of Jatropha urens. Science 40: 609-610.

Macbride, J.F. 1951. Euphorbiaceae. In: Macbride, J.F. Flora of Peru. Field Museum of Natural History 13: 1-200.

McVaugh, R. 1944. The genus Cnidoscolus: generic limits and intrageneric groups. Bulletin of the Torrey Botanical Club 71: $457-474$

Miller, K.I. \& Webster, G.L. 1961. A study of the relationship between Cnidoscolus and Jatropha. American Journal of Botany 48 : $1-548$.

Miller, K.I. \& Webster, G.L. 1962. Systematic position of Cnidoscolus and Jatropha. Brittonia 14: 174-180.

Miller, K.I. \& Webster, G.L. 1966. Chromosome numbers in the Euphorbiaceae. Brittonia 18: 372-379.
Mori, S.A.; Silva, L.A.M.; Lisboa, G. \& Coradin, L. 1989. Manual de manejo do herbário fanerogâmico. Ilhéus, Centro de Pesquisas do Cacau.

Mors, W.B. \& Rizzini, C.T. 1966. Useful Plants of Brazil. London, Amsterdam, Holden-Day Inc.

Muenscher, W.C. 1958. Euphorbiaceae. Pp. 142-152. In: W.C. Muenscher. Poisonous plants of the United States. New York, The Macmillan Company.

Müller, J. 1865. Jatropha. Pp. 207-212. In: J. Müller. Linnaea, Journal für Botanik Pflanzenkunde.

Müller, J. 1866. Jatropha. Pp. 1076-1105. In: A.P. De Candolle. Prodromus systematics naturalis regni vegetabilis. Paris, Victor Masson et filii.

Müller, J. 1873. Euphorbiaceae. Pp. 1-752. In: C.F. Martius. Flora Brasiliensis. Munique, Lipsiae.

Nowicke, J.W. 1994. A palynological study of Crotonoideae (Euphorbiaceae). Annals of the Missouri Botanical Garden 81: 245-269.

Passos, R.A.M. 1993. Favela, determinações químicas e valor nutritivo. Revista da Sociedade Brasileira de Zootecnia 22: 451-454.

Pax, F. 1910. Euphorbiaceae-Jatropheae. Pp. 1-148. In: A. Engler. Das Pflanzenreich regni vegetabilis conspectus. Weinheim, H.R. Engelmann.

Pax, F. \& Hoffmann, K. 1914. Euphorbiaceae-AcalypheaeMercurialinae. Pp. 397-401. In: A. Engler. Das Pflanzenreich regni vegetabilis conspectus. Weinhelm, H.R. Engelmann.

Pax, F. \& Hoffmann, K. 1924. Euphorbiaceae - additamentum VII. Pp. 191. In: A. Engler \& Prantl. Das Pflanzenreich regni vegetabilis conspectus. Weinhelm, H.R. Engelmann.

Pax, F. \& Hoffmann, K. 1931. Euphorbiaceae. Pp. 11-233. In: A. Engler. Die natürlichen Pflanzenfamilien. 2 ed.

Pohl, J.E. 1827. Cnidoscolus. Pp. 56-63. In: J.E. Pohl. Plantarum brasiliae icones et descriptiones. Vindobanae.

Pott, A. \& Pott, V.J. 1994. Plantas do Pantanal. Corumbá, Empresa Brasileira de Pesquisa Agropecuária, Centro de Pesquisa Agropecuária do Pantanal.

Punt, W. 1962. Pollen morphology in the Euphorbiaceae with special reference to taxonomy. Wentia 7: 1-116.

Radford, A.E.; Dickison, J.R.M.; Massey, J.R. \& Bell, C.R. 1974. Vascular plant systematics. New York, Harper \& Row Publishers.

Rodal, M.J.N.; Nascimento, L.M. \& Melo, A.L. 1999. Composição florística de um trecho de vegetação arbustiva caducifólia, no município de Ibimirim, PE, Brasil. Acta Botanica Brasilica 13: $1-114$.

Rudall, P.J. 1987. Laticifers in Euphorbiaceae - a conspectus. Botanical Journal of the Linnean Society 94: 143-163.

Sales, M.F.; Mayo, S.J. \& Rodal, M.J.N. 1998. Plantas vasculares das florestas serranas de Pernambuco - um cheklist da flora ameaçada dos Brejos de Altitude - Pernambuco Brasil. Recife, Imprensa Universitária, UFRPE.

Santa Rosa, J. 1943. Óleo de Favela, nova riqueza da região das secas. Rio de Janeiro, Instituto Nacional de Tecnologia.

Soukup, J. 1968. Las erythroxilaceas y las euphorbiaceas del Peru, sus génerus e lista de espécies. Biota 55: 113-149.

Stafleu, F. \& Cowan, R.S. 1976. Taxonomic Literature. Utrecht, Bohn, Schetelma \& Holkema.

Thurston, E.L. \& Lestern, N.R. 1969. The morphology and toxycology of plant stinging hairs. Botanical Review 35: 393-412.

Webster, G.L. 1994. Classification of the Euphorbiaceae. Annals of the Missouri Botanical Garden 81: 3-32.

Webster, G.L. \& Rupert, E.A. 1973. Phyllogenetic significance of pollen nuclear number in the Euphorbiaceae. Evolution 27: 524-531.

Williams, L. 1962. Laticifers plants of Economic Importance II. Mexican chilte (Cnidoscolus): A source of gutta-like material. Economic Botany 16: 53-70.

Versão eletrônica do artigo em www.scielo.br/abb e http://www.botanica.org.br/acta/ojs 